\begin{tabular}{|c|c|c|c|}
\hline & RESEARCH ARTICLE & ARAŞTIRMA MAKALESİ & \\
\hline Title of Article & \multicolumn{2}{|c|}{$\begin{array}{c}\text { Analyses of Spatial Pattern and } \\
\text { Connection Established with Water on } \\
\text { Porsuk Riverfront, Eskisehir }\end{array}$} & 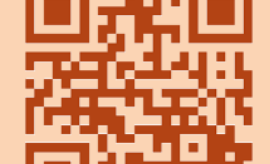 \\
\hline $\begin{array}{l}\text { Corresponding } \\
\text { Author }\end{array}$ & \multicolumn{2}{|c|}{$\begin{array}{l}\text { Ayşe Deniz YEŞiLTEPE } \\
\text { Eskişehir Teknik Üniversitesi, Mimarlık ve Tasarım Fakültesi, Mimarlık Bölümü, } \\
\text { adbulut@eskisehir.edu.tr }\end{array}$} & \\
\hline $\begin{array}{l}\text { Received Date } \\
\text { Accepted Date }\end{array}$ & \multicolumn{2}{|l|}{$\begin{array}{l}26.06 .2020 \\
01.10 .2020 \\
\end{array}$} & \\
\hline $\begin{array}{l}\text { Author / } \\
\text { Authors }\end{array}$ & $\begin{array}{l}\text { Gül ŞiMŞ̧EK } \\
\text { Ayşe Deniz YEşiLTEPE }\end{array}$ & $\begin{array}{l}\text { ORCID: 0000-0002-5123-323X } \\
\text { ORCID: 0000-0002-0427-8849 }\end{array}$ & \\
\hline How to Cite & \multicolumn{2}{|c|}{$\begin{array}{l}\text { ŞiMSSEK, G. and YEŞiLTEPE, A.D. (2020). Eskişehir Kenti Porsuk Çayı Kıyısında } \\
\text { Mekânsal Örüntü ve Suyla Kurulan Bağlantının Analizi, Kent Akademisi, Volume, 13, } \\
\text { Issue 3, Pages, 487-512. }\end{array}$} & $\begin{array}{l}\text { Kent Akademisi } \\
\text { Urban Academy }\end{array}$ \\
\hline
\end{tabular}

\title{
Eskişehir Kenti Porsuk Çayı Kıyısında Mekânsal Örüntü ve Suyla Kurulan Bağlantının Analizi
}

\section{ABSTRACT:}

Cities are identified by a combination of geography, culture, architecture, site-specific characteristics, policies and patterns of growth. One key identifying characteristic of many cities around the world are the ways in which bodies of water (rivers and streams) through, marking one of the basic components of this multidimensional formation. Porsuk Stream, in the city of Eskişehir is an example of a key hydrological element that shapes its landscape. Porsuk Stream affects and is affected by the city. As it continues its path from East to West, cuts the city into two equal territories. In the early 2000s, an extensive rehabilitation practice was carried out on Porsuk Stream, which was confronted with the negative effects of a rapid urbanization process. This practice, in general terms, also led to the revitalization of Porsuk waterfront in the city center and its immediate surroundings and strengthened the relationship between the city and the water. However, the experience of place in relationship to the waterfront differs in other parts of the city along the water's edge. This study evaluates different user experiences of Porsuk Stream, based on the differences in the spatial patterns of the city. Two successive methods are followed for this purpose: the first one utilizes Serial Vision Analysis (SVA) regarding structure features, patterns, spacing, etc. on both sides of Porsuk Stream. The second explores subregions that emerge through SVA, types, identifying different levels of experience on the waterfront. The basic outcomes of the study reveal that Porsuk is a mostly passive element in the built environment, and user experiences are limited, with the exception of limited areas of access near the city center and parks. The means and levels of interaction between Porsuk and the riverfront vary in the regions determined along the research area. The result of this limited access to Porsuk prevents citizens from establishing a balanced and continuous interaction with the waterfront, with the exception of certain limited regions. The main reason behind this, is the relationship between Porsuk and the citizen is mainly due to policies and land development that favor of the built environment. When it comes to urban

\footnotetext{
${ }^{1}$ Atatürk University, Faculty of Architecture and Design, Department of City and Regional Planning, gulsims@hotmail.com

${ }^{2}$ Eskisehir Technical University, Faculty of Architecture and Design, Department of Architecture, adbulut@eskisehir.edu.tr
} 
rivers, approaches that integrate nature and the built environment should not be neglected. This research seeks to reveal the critical role that waterfront access plays in the health of the city and makes the case for design and planning interventions along the riverfront that create a balance between water and the city.

\section{KEYWORDS: Urban stream, Serial Vision Analysis, Urban space experience, Porsuk Stream, Eskişehir}

\section{ÖZ:}

Kentlerin kimlikleri, bulundukları alanın coğrafyası, kültürü, mimarisi, yere özgü değerleri ve kentin gelişiminde izlenen politikalar gibi unsurların bir bileşkesi olarak şekillenmektedir. Dünya üzerinde çok sayıda örnekte olduğu gibi kentlerin içinden geçen akarsular da bu çok boyutlu oluşumun temel ögelerinden biri olarak karşımıza çıkmaktadır. Eskişehir kenti içinden geçen Porsuk Çayı için de aynı durum söz konusudur. Düzenli bir akışa sahip olan Porsuk Çayı, kenti ikiye bölerek doğudan batıya doğru yoluna devam ederken kenti etkilemekte ve kentten etkilenmektedir. Hızlı kentleşme sürecinde olumsuz etkilerle karşı karşıya kalmış olan Porsuk Çayı üzerinde, 2000’li yılların başında kapsamlı bir rehabilitasyon gerçekleştirilmiştir. Bu uygulamanın, kent merkezi ve yakın çevresinde Porsuk Çayı kıyısını canlandırıcı ve kentin su ile kurduğu ilişkiyi kuvvetlendirici bir etkisi de olmuştur. Bununla birlikte, suyun geçtiği tüm kent parçalarında benzeri bir canlanmadan bahsedilememektedir. Porsuk güzergahı üzerinde farklı kent parçalarında farklı deneyim türleri bulunmaktadır. Bu çalışmada; Porsuk Çayı güzergahı üzerindeki deneyim türleri, kentin mekânsal örüntüsündeki farklılaşmalar baz alınarak değerlendirilmektedir. Bu amaçla, iki ardıl yöntem izlenmektedir; ilki, Porsuk Çayı'nın her iki yakasındaki yapılaşma özelliklerinin, dokunun, açıklıkların vb. değiştiği noktalara dair Seri Görünüm Analizinin (SGA) yürütülmesidir. İkincisi ise SGA yoluyla ortaya çıkan alt bölgeler üzerinden; akarsu güzergâhı üzerindeki deneyimlerin yerlerine göre tür ve düzeylerinin saptanmasıdır. Çalışmanın temel bulguları; Porsuk’un, kent merkezi ve parkların yer aldığı kent parçaları dışında, çoğu kez yapılı çevre içerisinde pasif bir eleman olarak seyretmekte olduğunu ve kullanıcı deneyimlerinin kısıtlı kaldığını göstermektedir. Çalışma alanında belirlenen bölgelerde Porsuk’un kent ile etkileşim araçları ve düzeylerinin farklılaşması dikkat çekmektedir. Bu durum, bazı bölgelerde aksi olsa da kent geneline bakıldığında Porsuk'un kentli ile dengeli ve sürekli bir etkileşim kurulamaması ile sonuçlanmıştır. Bundaki temel nedenin, Porsuk ve kentli ilişkisinin ağırlıklı olarak yapılı çevre lehinde alınan kararlarla kurulmuş olmasından kaynaklı olduğu tespit edilmiştir. Oysa, kentsel akarsular söz konusu olduğunda, doğa ile yapılı çevreyi bütünleştiren yaklaşımlar göz ardı edilmemelidir. Porsuk Çayı ile kent ilişkisinin güçlendirilebilmesi, akarsu kıyısında ve su ile arasındaki etkileşiminin sürekliliğinin gözetildiği türden müdahaleleri gerekli kılmaktadır.

ANAHTAR KELIMELER: Kentsel akarsu, Seri Görünüm Analizi, Kent mekanında deneyim, Porsuk Çayı, Eskişehir

\section{GİRIŞ:}

Genel olarak akarsu-kent ilişkisine bakıldığında; tarihin başlangıcından itibaren yerleşimlerin suya yakın alanlarda kurulmuş olduğu ve tarihin en büyük kültürlerinin geliştiği konumların su kenarları oldukları dikkat çekmektedir. Bir arazinin yerleşime elverişliliğini belirleyen temel faktör, o arazinin yeterince temiz ve bol suya sahip olup olmadığıdır. Akarsu kenarlarının ilk gelişen yerler olmalarının nedenleri, suya olan yakınlığın taşımacılık, sulama, sanayi, savunma gibi çok sayıda fonksiyon için en uygun koşulları sağlamasıdır (Adler, 2007, s.60). Kentsel akarsu kıyıları, kentlileri ekonomik ve rekreasyonel aktiviteye teşvik etmektedirler.

Akarsuların insanlığın gelişiminde oynadığı en önemli rol, göçmen kültürden yerleşik yaşam tarzına geçiş firsatı sunmasıdır. Kentleşme tarihinde akarsu, temel bir konum belirleyici faktör olmuştur. Bugün de içinden akarsu geçen kentlere baktığımızda; Roma'dan Tokyo'ya dek kentlerin oluşumu, formu, gelişimi ve canlılığında akarsuların rolünü görmek mümkündür. Akarsular, içmek, evsel kullanım, atıkların bertarafi ile sulama ve hayvancılık için temiz su sağlamaktadır. Tüm bu avantajlar ve balık gibi temel besin maddelerinden birini de sunması, yerleşmek için toplumlara geçerli sebepler sunmuştur. Akarsular, dışarıdan gelen düşmanca tehditlere karşı kolay koruma da sağlamış ve gemi taşımacılığı gibi ekonomik teşebbüsleri de hızlandırmıştır. Akarsuyun gelişime yaptığ bu katkılar, kentsel akarsuların iki yönlü doğasında gömülü dualitenin olumlu tarafına işaret etmektedir. Olumsuz tarafinda ise akarsuların doğadan koparılma süreçlerinde yapılaşma lehine aşılan sınırlardan kaynaklanan kirlilik, taşkın, kapatılarak yok edilme gibi süreçler ve tecrübeler yer almaktadır (Şimşek, 2014). 
Akarsular ve yakın çevreleri, ekolojik değerleri yüksek doğal alanlar olarak da öne çıkmaktadırlar. Ekolojik değerlerine eşlik eden özellikler; su kaynağı olmaları, görsel çekicilik, kullanım değerleri, üzerinde ya da kıyısında yapılan rekreasyonel faaliyetlere olanak sunmaları gibi bir yelpazeyi içermektedir. Bu özellikler aynı zamanda akarsu ve yakın çevrelerinin birer ekonomik kaynak olarak da değerlendirilmesine olanak tanımaktadır. Bu anlamda akarsukent ilişkisi, tarih boyunca var olan su-insan etkileşiminin en sofistike biçimlerinden biri olarak kendini göstermektedir. Bu ilişki, doğal dinamiklerin yanı sıra kentsel akarsuları bir kültür nesnesine de dönüştürerek kent kimliğinin bir parçası haline getirmektedir. 2009 yılında ABD'de yapılan bir araştırmanın sonucuna göre kentliler; kayıkla gezinti, balık tutma, yaban yaşamı gözleme, güneşlenme gibi suya dayalı aktivitelerde bulunabildikleri mekânları ziyaret etmeyi diğer kentsel mekânları ziyaret etmeye tercih etmektedirler (Booth ve Bledsoe, 2009'dan akt. Özeren ve Hepcan, 2013). Tüm bu bileşenler kentsel akarsuları kentin sosyal, kültürel ve ekonomik gelişimine katkı yapacak potansiyeli barındıran öğeler olarak ele alınmasına destek olmaktadır ve gerekli kılmaktadır.

Bir yerleşim alanındaki akarsular için köprüler, bir kıyıyı diğerine bağlamalarıyla akarsuyun kent ile olan bağlantısında temel faktördür. Her akarsu kıyısı, bir köprüyü geçerek akarsuyun karşı kıyısına bağlanmaktadır. İçinden akarsu geçen kentlerde akarsuyu aşan köprüler, o kentin morfolojik anlamda en belirleyici ve görsel olarak en tanımlanabilir parçalarındandır. Köprüler yalnızca estetik açıdan belirgin bir rol oynamamakta, aynı zamanda akarsu yakaları arasında kurulan bağlantılar ve ulaşım üzerinde de büyük bir etkisi bulunmaktadır. Köprüler, gemi taşımacılı̆̆ı veya tüneller gibi tüm diğer yollar içinde, akarsuyun iki yakasını birbirine bağlamakta kullanılan en yaygın olan yoldur (Hölzer, vd.'den akt. Abshirini \& Koch, 2016; Manning, 1997'den akt. Silva, Saraiva, Ramos, \& Bernardo, 2012). Buna ek olarak köprüler aynı zamanda, kentlerde kültürel anlamın da taşıyıcıllğını yapmaktadır (Chang ve Choo 2009; Ioannidis 2011; Psarra 2012'den akt. Abshirini \& Koch, 2016). Bu açıdan, kent ile akarsu arasındaki ilişkinin birer parçası olarak, köprüler de önemli bir yere sahiptir. Köprülerin sayısı ve trafik yoğunluğu erişim için önemli birer faktör olmakla birlikte, asıl hesaba katılması gereken, yaya olarak ve bisikletle geçilen köprülerin varlı̆̆ı ve sayısıdır (Silva, Saraiva, Ramos, \& Bernardo, 2012).

Bir akarsu ve onun kentsel bağlamı, insanlar tarafından erişilebilir açık bir alan olarak tanımlanan ve insanların bireysel ve toplumsal aktivitelerini gerçekleştirebildikleri alanlar olarak analiz edilebilir. Akarsu kıyısındaki toplumsal aktiviteler, insanlar ile akarsu arasındaki etkileşimde büyük rol oynamaktadır. Akarsu kıyılarında yer alan, insan eliyle oluşturulmuş kentsel alanlar ile daha az stresli, sessiz ve suyla iç içe doğal alanlar arasındaki etkileşim yoluyla kentsel peyzaj zenginleşmektedir. Akarsu kıyısı ve köprüler üzerinde çevre duyarlı ulaşım türleri olarak nitelendirilebilecek yaya ve bisiklet yolları da su, manzara ve peyzaj ile daha yakın bir ilişki kurulmasını sağlamaktadır. Bu anlamda, erişilebilirlik, su ile temas konusunda belirgin bir yere sahiptir (Silva, Saraiva, Ramos, \& Bernardo, 2012).

Akarsuya erişimin bir başka türü de akarsu üzerinde gerçekleştirilen su taşıtları ile erişimdir. Su taşıtları vasıtasıyla, akarsu üzerinde akarsudan kente bakma deneyimi yaşanmakta, bunun yanı sıra teknelerin ve iskelelerin varlı̆̆ı, akarsuyun taşımacılıkta da kullanımına işaret etmektedir. Akarsu kıyısında, özel araçların kullanımının ve otopark yüzeylerinin ise akarsuyun görsel çekiciliği üzerinde olumsuz etkisi bulunmaktadır. Büyük kentsel yollar veya demiryolları için bir koridor haline gelme durumlarında, yoğun trafik kaynaklı birer sorun alanı da tanımlayabilmektedir (Manning, 1997'den akt. Silva, Saraiva, Ramos, \& Bernardo, 2012).

Kentlerimiz büyüdükçe altyapılarına ve çevresel açıdan iyileştirilmelerine yeniden yatırım yapma gereği ortaya çıkmaktadır. On yıllarca ihmal edildikten sonra, 20. yüzyılın ikinci yarısından itibaren kaynakların sürdürülebilirliğine verilen önemin artmasıyla birlikte, kentsel akarsular üzerindeki farkındalık artmaktadır. Kentsel akarsular, kentin kendisinden ayrıştııılamaz bir sistem olarak kent mekânı ile etkileşim halindedirler. Toyoda vd. (2007) (akt. Fukushima ve Uchida, 2016), akarsu kıyısının mekânsal biçimlenmesindeki farklılıklar ile sakinlerin tutumları ilişkisini değerlendirmişlerdir. Kullanıcıların tercihlerinden, mekânsal örüntüde, yaya mekanlarında yürüyüş gibi özellikle akarsu kıyısı kullanım türlerinin belirleyici olduğunu ortaya koymuşlardır. Özeren ve Hepcan (2013), Silva, Saraiva, Ramos, \& Bernardo (2012), Abshirini \& Koch (2016) ve Fukushima ve Uchida'nın (2016) değerlendirmeleri bir araya getirildiğinde, akarsuyun ve kıyısının deneyimlenmesinde öne çıkan kullanımlar; su 'üzerinde' manzara izleme, gezinti, balık tutma, 'kenarında' yürüyüş, oturma, dinlenme ve 'içinde' su araçlarıyla gezinti, yüzme olmaktadır.

Bu çalışmanın amacı, Anadolu'nun önemli kentlerinden olan Eskişehir'de kentsel odak olarak görülen Porsuk'un, kentin doğal ve yapılı çevresini oluşturan ögelerle ve böylece kentliyle kurduğu etkileşimi mekânsal bağlamda analiz etmektir. Bu çalışma kapsamında, literatürde akarsuyun ve kıyısının deneyimlenmesinde öne çıkan kullanımlara ilişkin, mekân bağlamında bir değerlendirme yapılması amaçlandığından deneyimlendikleri mekan üzerinden üst başlıklar altında (kenarında, üzerinde ve içinde olmak üzere) kategorilendirilmesi uygun bulunmuştur. Akarsu kıyısını 
içeren kent parçalarında izlenen mekânsal örüntü ve su ile kullanıcı arasındaki bağlantının araçlarına dair analizler birlikte değerlendirildiğinde, akarsu kıyısı ve kentin bütünleşme düzeyi hakkında ipuçları veren bulgulara ulaşılabilmektedir. Yürütülen analizlerin bulgularının, Porsuk Çayı ile kent ilişkisinin güçlendirilebilmesine yönelik öneriler geliştirebilmesinde yol gösterici olacağı ve Porsuk'u içine alan plan\&projeler için mekân bağlamında bir çerçeve sunabileceği düşünülmektedir. Daha önce ülkemizde Eskişehir ya da bir başka kent özelinde bu kapsamda bir çalışmanın yürütülmemiş olması, araştırmanın özgün yönünü oluşturmaktadır.

Mekânsal örüntünün hangi noktalarda ve ne yönde değiştiğini tespit etmek amacıyla, iki adımlı bir yöntem takip edilmektedir: İlki, Porsuk Çayı'nın her iki yakasındaki yapılar, anıtlar, açıklıklar, yönlenmeler ve sınırlara dair yürütülen seri görünüm analizidir. Bu analiz, güzergâhın uzunluğundan dolayı, suyun hemen bitişiğindeki adalar ile ve bu parçalarda dokunun değişim gösterdiği konumlarla sınırlı tutulmuştur. İkinci adımın yöntemi ise mahalle sınırları baz alınarak ve ardından seri görünüm analizi yoluyla ortaya çıkan alt bölgeler üzerinden; akarsu ile kentli arasındaki etkileşimin mekânsal bağlamdaki türüne yöneliktir: $\mathrm{Bu}$ yolla, deneyimin yeri (içinde, üzerinde veya kenarında) üzerinden kullanım aracı (bkz. Bölüm 3.3) saptanmaktadır. Yapı boyutunda kurulabilen etkileşim pencere, balkon ya da teras olabilmekte, bunlardan en az bir özellik her yapıda bulunduğu için su kenarı yapıları da bu kategoride tek başlik olarak yer verilmektedir.

\section{Araştırma Alanı: Eskişehir Kenti Porsuk Çayı Güzergahında Mekânsal Örüntü}

Porsuk Çayı Kütahya'dan doğup Eskişehir kenti içinden geçerek Sakarya Nehri'ne dökülmektedir. Eskişehir kent merkezini de içerecek şekilde kent içinden geçen Porsuk Çayı, kentin temel bir kimlik ögesi olmuştur (bkz. Resim 1). Düzenli bir akışa sahip olan Porsuk Çayı, kenti 'çapsal' ${ }^{3}$ olarak ikiye bölerek yoluna devam etmektedir (bkz. Şekil 1). Kentin bir akarsu tarafindan ikiye bölünmesi, kente zaman zaman kirlilik, koku, ulaşım gibi konularda olumsuzluklar getirmiş olsa da Porsuk Çayı, bir kentsel akarsuyun iyi yönetildiğinde kent kimliğine ne derece olumlu etkilerde bulunabildiğine dair iyi örneklerden biridir.

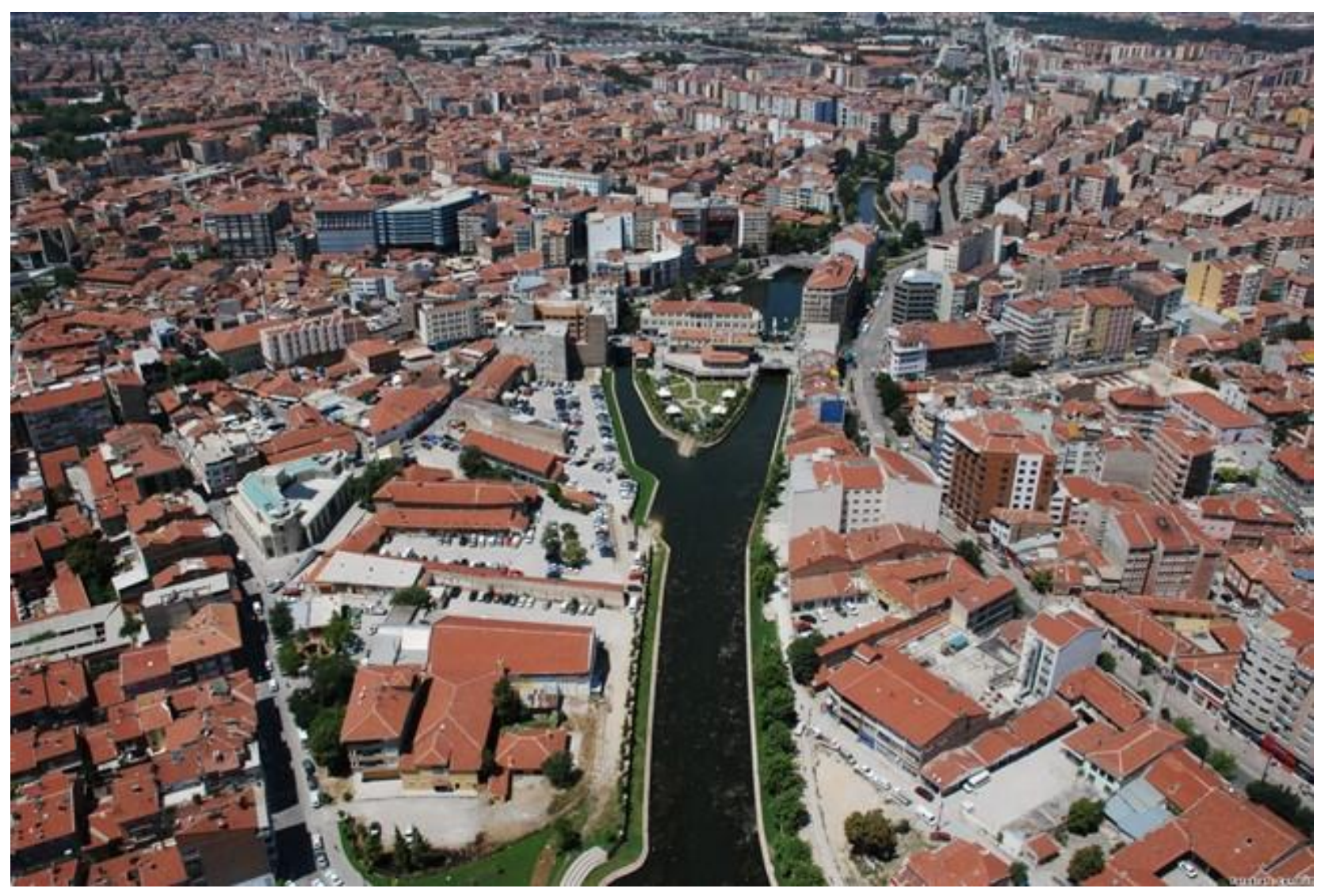

3 “Bir bütünü yaklaşık iki eş parçaya bölecek biçimde, merkezden geçen” tanımının karşılığı olarak kullanılmıştır.

Eskişehir Kenti Porsuk Çayı Kıyısında Mekânsal Örüntü ve Suyla Kurulan Bağlantının Analizi

Journal of Urban Academy | Volume: 13 Issue: 3 | ISSN: 2146-9229

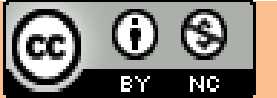




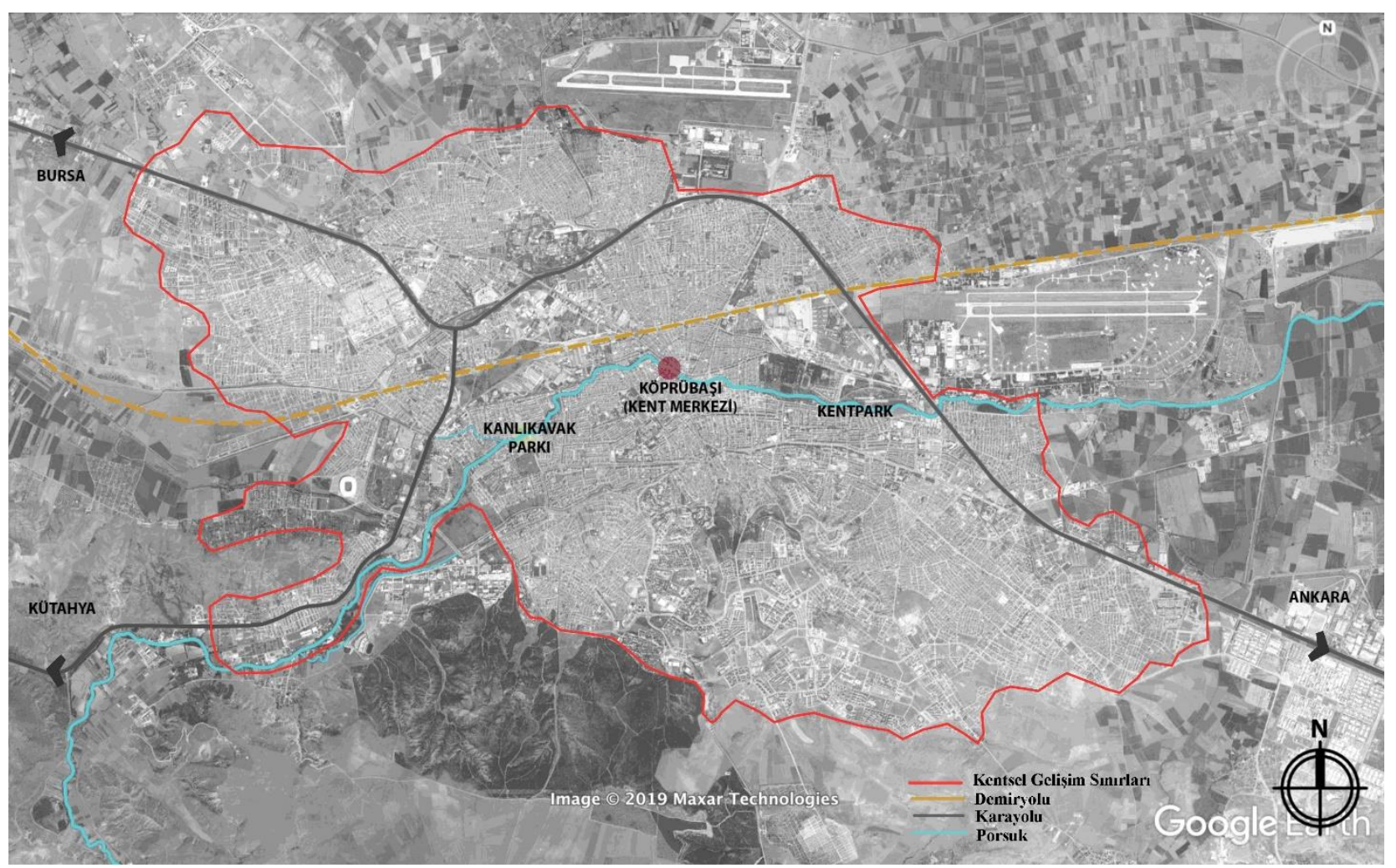

Şekil 1. Eskişehir Kenti ve Porsuk Çayı Güzergâhı (Google Earth görüntüsü üzerinden üretilmiştir)

Kentin tarihinde geçmişe gidildiğinde, zaman zaman karakteri değişmekle birlikte, Porsuk'un Eskişehir için taşıdığı anlamın izlerini takip etmek mümkündür. 1960'lı yıllarla birlikte ağıllı̆̆ını hissettiren kentleşme ve sanayileşme baskısı öncesinde Porsuk, balık tutulan, kayıklarla gezilen, etrafında çay bahçeleri, mesire alanları ve hatta değirmenler bulunan bir kent içi akarsudur. 1990'lara gelindiğinde yoğun, kirli ve trafik sorunlarının baş gösterdiği bir kente dönüşen Eskişehir'de, kentin merkezinden geçen ve kente hayat veren Porsuk Çayı'nın da nüfusun artmasıyla birlikte kirlenmiştir. 2000'lerin başına gelindiğinde Porsuk, Eskişehir Büyükşehir Belediyesi tarafından kapsamlı bir rehabilitasyon çalışmasının konusu olmuş ve kent yaşamına yeniden kazandırılmıştır.

Porsuk Çayı'nın Eskişehir kentine yeniden kazandırılması ile birlikte özellikle merkez ve çevresinde Porsuk kıyıları çekim merkezi haline gelmiştir. 2001 yllında gerçekleştirilen proje ile Eskişehir Büyükşehir Belediyesi (EBB), Avrupa Yatırım Bankası'ndan temin ettiği kredi ile öz kaynaklarını birleştirerek 'Kentsel Gelişim Projesi' kapsamında Porsuk Çayı'nın kent geçişini oluşturan yaklaşık 10 kilometrelik bölümünü rehabilite etmiştir. Projenin Porsuk ile ilgili temel bileşenleri; taşkın güvenliğini sağlamak üzere kapak sistemi yapmak, köprülerin ve akarsu civarı yapıların deprem güvenliğini arttırmak, akarsuyun gezi amaçlı kullanılmasını sağlamak ve kentin yeşil alan donatı ihtiyaçlarını karşılamak olmuştur. İkinci bileşen kapsamında, Porsuk üzerindeki 24 araç ve yaya köprüsü yeniden inşa edilmiş, akarsu yatağı güçlendirme çalışmaları yapılmış ve kentsel alan içinde kalan kanallar yenilenmiştir. Kentsel Gelişim Projesi'nin bileşenleri ise daha kapsamlıdır: (1) Porsuk Çayı'nın da geçtĭgi kent merkezinde düğüm noktası bulunan tramvay projesi, (2) afet zararlarını azaltma amaçlı alınan önlemler ve (3) yağmur suyu, içme suyu ve atık su kanallarının yenilenmesi, atık su arıtma tesislerinin kurulması (Şimşek, 2011).

Porsuk Çayı, Adalar bölgesindeki kent merkezi (Köprübaşı) içinden geçmekte, Porsuk ile kentin çok sayıda odak noktası niteliğindeki yoğun kullanım alanı arasında bağlantı bulunmaktadır. Porsuk etrafındaki yollar, akarsuya paralel biçimde, merkezde çoğu kez suyun her iki tarafında devam etmekte ve bu yollara dik uzanan yollar kent içinde 
yönlenmeye yardım etmektedir. Bu niteliği güçlendirmek için proje kapsamında; Köprübaşı etrafında yaya erişimi geliştirilmiş, pek çok cadde ve sokak (Doktorlar Caddesi ve Hamamönü Caddesi gibi) yayalaştırılmıştır. Yine 2000'li yıllarla birlikte kente kazandırılmış olan Bilim, Sanat ve Kültür Parkı, Kentpark ve Kanlıkavak gibi kentteki büyük parkların yer seçiminde akarsu, temel unsurdur (Şimşek, 2011).

Topolojik olarak bir arter niteliğinde olan Porsuk, hem kentin mekânsal gelişimini yönlendirmede etkili olmuş hem de mekânsal dönüşümlerin tetikleyicisi olmuştur. Bu dönüşümler, su kenarındaki yapılaşma hakları, ticari fonksiyonların gelişimi, açık ve yeşil alanların düzenlenmesi gibi uygulamaları getirmiştir. Porsuk Çayı'nın geçtiği güzergâhın yakın çevresindeki mekânsal dönüşümlerin yanında Porsuk üzerine yapılan köprüler de kent kimliğinin birer parçası olmuşlardır. Zamanla yıpranmış olan köprülerin etkin kullanım düzeyleri düşmüş ve 2000'li yılların başında güvenlik nedeniyle yenileri ile değiştirilmiştir. Orijinal köprüler şimdi yerlerinde olmamakla birlikte, köprülerin kent için taşıdığı anlam benzer şekilde sürmektedir.

\section{Yöntem}

$\mathrm{Bu}$ araştırmada, akarsuyun ve kıyısının deneyimlenmesinde öne çıkan kullanımlar, mekân bağlamında atanan üst başlıklar altında ve suyla bağlantı kurmayı sağlayan araçlar (fiziksel unsurlar) üzerinden değerlendirilmektedir. Literatürde akarsuyun ve kıyısının deneyimlenmesinde öne çıkan kullanımların, mekân bağlamında değerlendirilmesine olanak sunmak üzere belirlenen üst başlıklar; içinde, üzerinde ya da kenarında kategorileridir. Bu kategoriler altında, mekânsal olarak akarsuyun içinde, üzerinde ya da kenarında yer alan, suyla bağlantı kurmayı sağlayan fiziksel unsurların var olup olmadığına yönelik bir tespit yapılmıştır. Bu tespit ve değerlendirme öncesinde, çalışma alanı büyüklüğünden dolayı, mekânsal örüntüdeki farklılaşmaya göre bölgelere ayrılmıştır. Böylelikle, ayrılan her bir bölge özelinde, kullanıcının Porsuk Çayı ile bağlantı kurma yerlerine, araçlarına ve araçlardaki çeşitlenmeye ilişkin bilgiye ulaşılabilmektedir. Akarsu ve kullanıcı arasında kurulan bağlantının sosyal, psikolojik, vs. yönlerinin değerlendirilmesi bu çalışmanın kapsamı dışında yer almaktadır.

$\mathrm{Bu}$ çalı̧̧mada yalnızca akarsuyun kendisi değil, yakın çevresi araştırmaya dahil edildiğinden, akarsu yakın çevresine yönelik olarak kullanılan iki temel kavrama bakmakta fayda görülmektedir: 'Akarsu kıyısı/kenarı' (riverfront) kavramı, akarsu ile yapıların ilk sırası arasındaki doğrudan bağlantı alanıdır ve genellikle bazı tanımlayıcıların coğrafi bağlamını belirlemek için kullanılmaktadır. 'Akarsu koridoru' (river corridor) kavramı ise su yolunu içeren ve değerlendirme yöntemini destekleyen, kentsel alanda çoğu kez ilk yapı sırası ile sınırlı kalmayan daha geniş bir alana karşılık gelmektedir. Daha basit bir tanıma göre akarsu koridoru, akarsuyu içine alan yaklaşık 500 metrelik bir tampon ile tanımlanabilir (Silva, Saraiva, Ramos, \& Bernardo, 2012). Bu mesafe, akarsu ve insanlar arasında kurulabilecek yakın ilişkiler göz önüne alındığında tatminkâr ve makul görünen bir yürüyüş mesafesine karşılık gelmektedir. Buna göre belirlenen çalışma alanı, kentsel iyileştirme ya da akarsu rehabilitasyon süreçlerinin işletilebileceği ve metodolojinin uygulanabilirliğinin sağlanabileceği bir büyüklüğe işaret etmektedir. Bununla birlikte, bu akarsu koridoru sınırı belirlenirken; yol ağı, sırtlar veya havza görüş alanları gibi faktörler de dikkate alınmalıdır (Silva, Saraiva, Ramos, \& Bernardo, 2012). Bu çalışma kapsamında dikkate alınan alan, akarsuya bakan yapı adalarının ilk sırasını içerdiğinden 'akarsu kıyısı' kavramının kullanılması benimsenmiştir. Bu doğrultuda, Porsuk Çayı'nın kent içinde kalan kısmında, akarsuyun her iki yakasında ilk sıradaki yapı adaları, alan çalışmasının yürütüleceği kent parçaları olarak tespit edilmiştir.

Araştırma kapsamında iki ardıl analiz uygulanmaktadır; bu analizlerden ilki, Seri Görünüm Analizidir (SGA). 'Seri görünüm' (serial view) ${ }^{4}$ analizi, kentsel tasarımcı Gordon Cullen tarafindan geliştirilmiştir. Cullen 1961'de yayınladığı 'Townscape' (Kent Peyzajı) kitabında seri görünüm analizini, bir yayanın kentte dolaşırken deneyimlediklerini nitelemek için kullanmaktadır. Cullen'e (1961) göre iki tür görünüm vardır; hâlihazırda bulunulan konumdaki görünüm ve ileride beliren görünüm. Bulunulan konumdaki görünümün beliren görünümlere doğru değişim sıklığının, kent içindeki yürüme deneyimi üzerinde etkisi vardır. Örneğin; dönemeçli bir patika izlerken, bir avluya girerken veya bir köşeyi dönerken yayanın görüşü sürekli olarak değişir. Bu durumlarda değişen görüş bir keşif ve drama hissi sağlarken, düz uzun bir yol ise monotondur çünkü başta algılanan görünüm, ileride algılanacak olandan farklı değildir.

Cullen'e göre kentsel doku, tek tek yan yana gelmiş olan yapıların ötesinde, çok sayıda yapı ve mekânın oluşturduğu bir görsel deneyimdir. Hareketli bir algı sağlayan bu deneyim, içinde hareket ederken görünümlerin ne yönde

\footnotetext{
${ }^{4}$ Kavramın, 'seri görüş', 'ardıl görünüm' şeklinde çevirileri de bulunmaktadır.
} 
değiş̧tiğini görsel açıdan belgeleme imkânı sunarak kentsel tasarım düşüncemizi de zenginleştirmektedir (Çalışkan, 2017). Niteliksel ve yer bazlı analizler, bir mekânın öne çıkan özelliklerinin tanımlanmasına, korunmasına ve geliştirilmesine yardımcı olmaktadırlar. Seri görünüm analizi de hareket halindeyken gerçekleştirilen görsel bir analiz olarak, dolaşılan mekânın fiziksel, doğal, kültürel ve tarihsel boyutlarının değerlendirilmesini sağlamaktadır (Horsman, 2013). Doğallık, bakım, görüş açıklığı (panoramalar, vistalar, kuşatılmışlık vb.), ön plan-arka plan ilişkileri ve zemin-yükseklik farklılıkları, bu çalışma kapsamında yürütülen analizde seri görünüm kapsamında değerlendirilen niteliklerdendir.

Çalışma alanının çerçevesi, batıda Kanlıkavak Parkı'ndan doğuda Kentpark’a kadar Porsuk Çayı kıyısı olarak belirlenmiştir. Çayın her iki yakasında, kentsel dokunun ve görüşün değiştiği konumlar haritaya işlenmiş ve fotoğraflanmıştır. Seri görünüm analizi uygulanırken, her adımda fotoğraf çekimi mümkün olmadığından iki temel teknikten bahsedilebilir: (I) Belli aralıklarla (örneğin 2 dakikada bir) fotoğraf çekilmesi (örneği için bkz. Horsman, 2013) ve (II) kent mekanındaki örüntünün (fonksiyonlarda farklılaşma, yapı yükseklik farkları, yapı yoğunluk farkları, açık-kapalı alan geçişleri, simgesel yapı/anıt varlığı vb. konularda) belirgin değişim gösterdiği parçaların fotoğraflanması. Bu araştırma kapsamında, bu analizin kapsamıyla bağlantılı olarak, ikinci teknik tercih edilmiştir.

Araştırma kapsamında yürütülen ikinci analiz, ilk analiz yardımıyla belirlenen bölgelerde, kullanıcının akarsu ile bağlantı kurma türlerinin saptanması ve bölgede var olan her bir göstergeye puan verilmesidir. Kullanıcının akarsu ile bağlantı kurma yeri ve araçlarına dair kategori ve göstergelerin belirlenmesinde; akarsu ve kıyısında sakinlerin kullanım tercihlerine yönelik kaynak bilgisinden yola çıkılmış, bununla birlikte kategoriler araştırmanın kapsamına yönelik olarak yazarlarca oluşturulmuştur. Kullanım yerine dair kategoriler ve aracına dair göstergeler ile düzeyine dair detaylara ilgili bölümde (Bölüm 3.3 ve Bölüm 3.4) yer verilmektedir.

\section{Analizler \& Bulgular}

\subsection{Seri Görünüm Analizi}

Seri görünüm analizi altlı̆̆ında, bulguların aktarılmasında tanımlayıcı olarak yararlanmak üzere, mahalle sınırlarını gösteren bir harita tercih edilmiştir. Mekânsal örüntünün parçalı yapısı, çalışma sahasının bölgeler üzerinden analize dahil edilmesini gerektirmiştir. Bölgeleri; mahallelerin tümü değil, mahallelerin akarsuyun iki yakasındaki ilk sıra yapı adalarına kadar olan kısımları (akarsu kıyısı/kenarı) oluşturmuştur. Çalışma alanında, akarsu kıyısı boyunca her iki yakada olmak üzere toplam 16 bölge saptanmıştır. Bu bölgeler ile seri görünümden gelen fotoğrafların çekildiği noktalar (yönleri ile birlikte) Şekil 2'de gösterilmektedir. Çalışma alanı, batıda Kanlıkavak Parkı ile doğuda Kentpark arasında kalan yaklaşık 7 km'lik hattı içermektedir. 


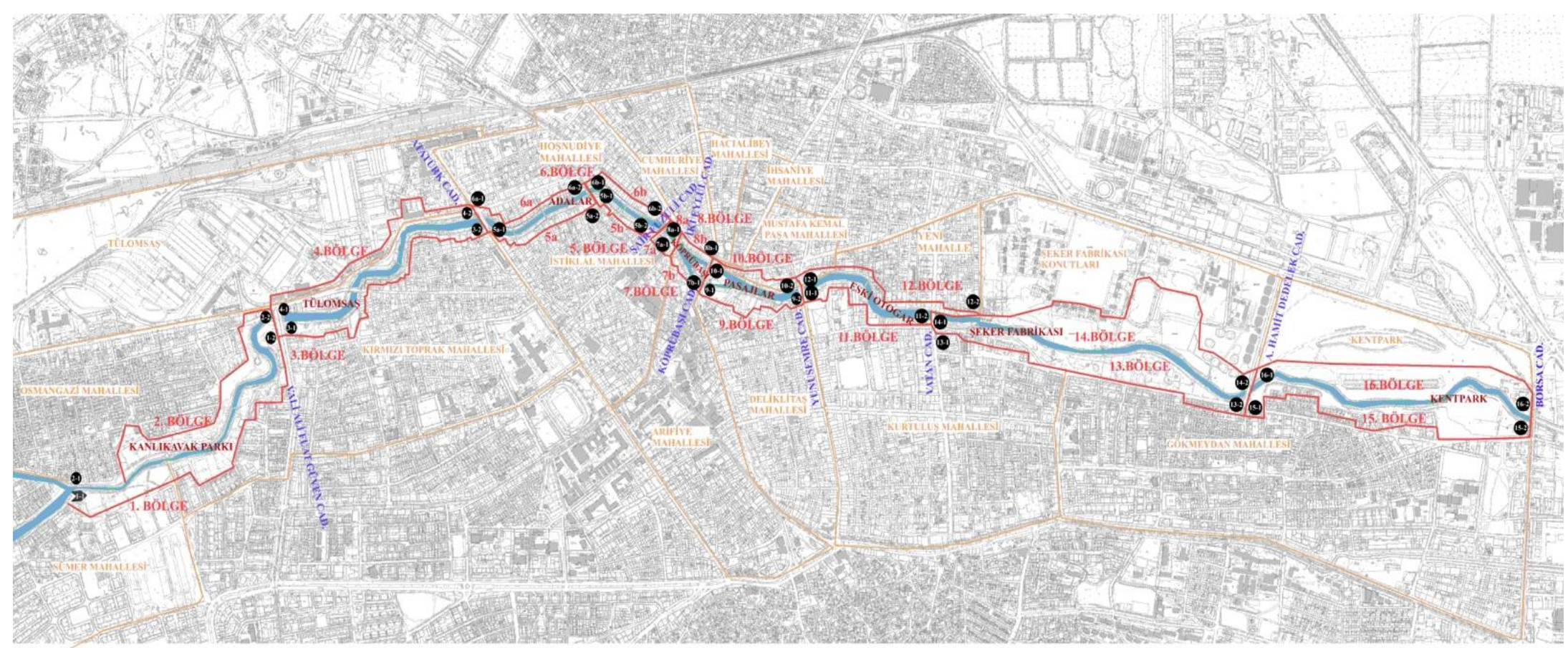

Şekil 2. Çalışma Alanında Saptanan Bölge Sınırlarını ve Seri Görünüm Analizi Kapsamında Çekilen Fotoğrafların Konumlarını Gösteren Harita 
1. ve 2. BÖLGELER (KANLIKAVAK BÖLGESİ)
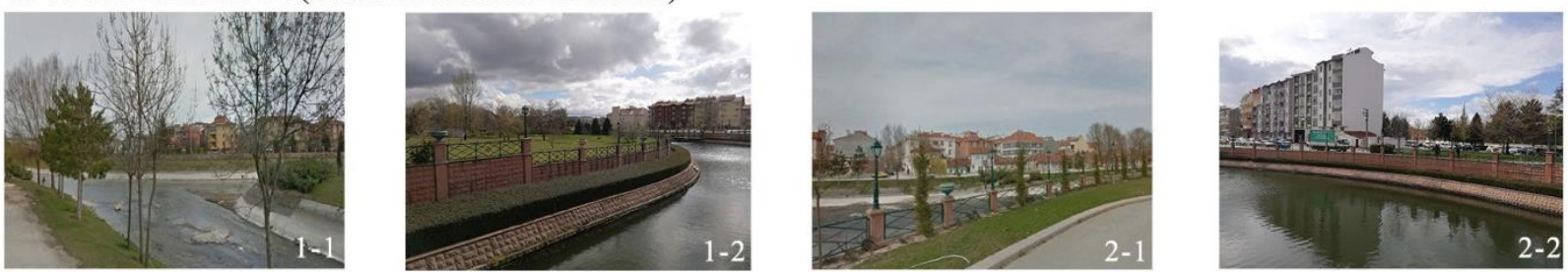

3. ve 4. BÖLGELER (TÜLOMSAŞ BÖLGESİ)
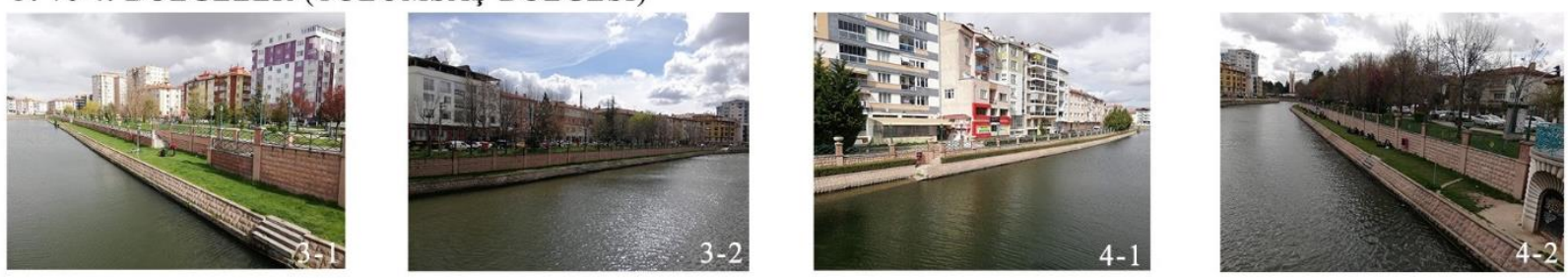

5a. ve 6a. BÖLGELER (ADALAR BÖLGESİ)
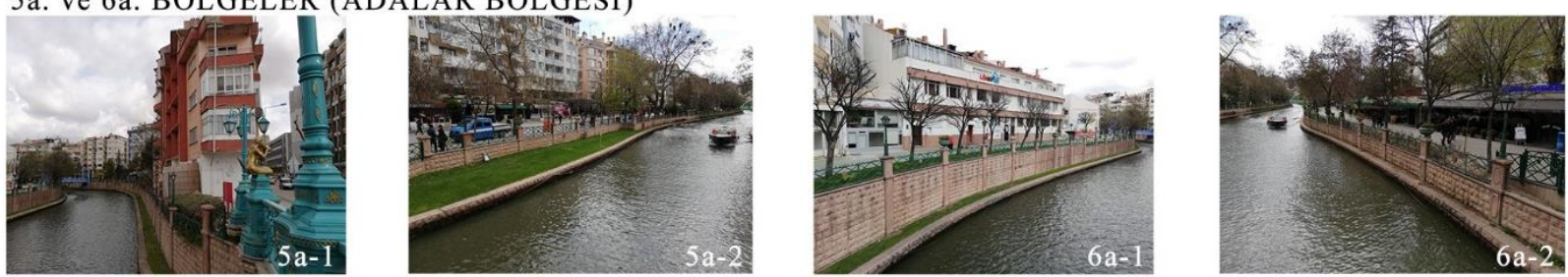

5b. ve 6b. BÖLGELER (ADALAR BÖLGESİ)
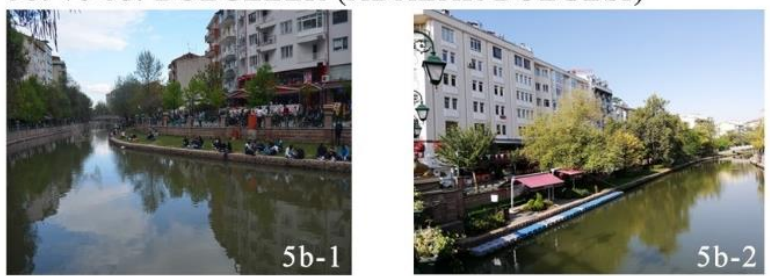

7a.ve 8a. BÖLGELER (KÖPRÜBAŞI BÖLGESİ)
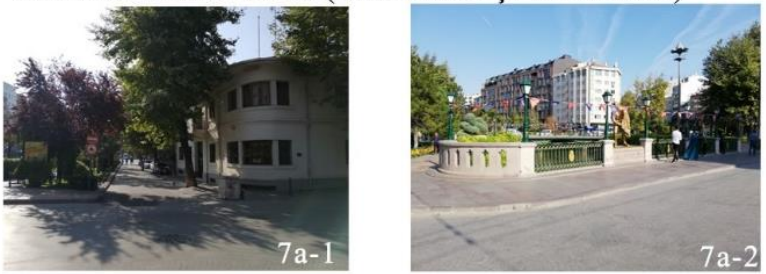

7b.ve 8b. BÖLGELER (KÖPRÜBAŞI BÖLGESİ)
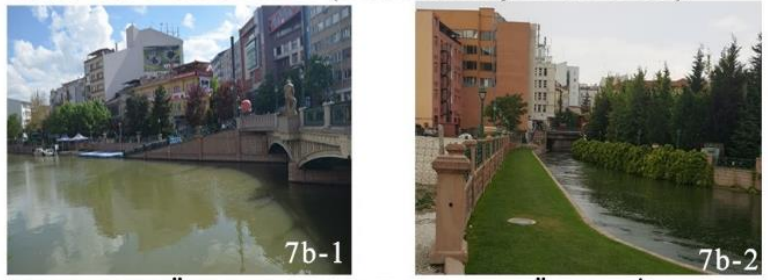

9. ve 10. BÖLGELER (PASAJLAR BÖLGESİ)
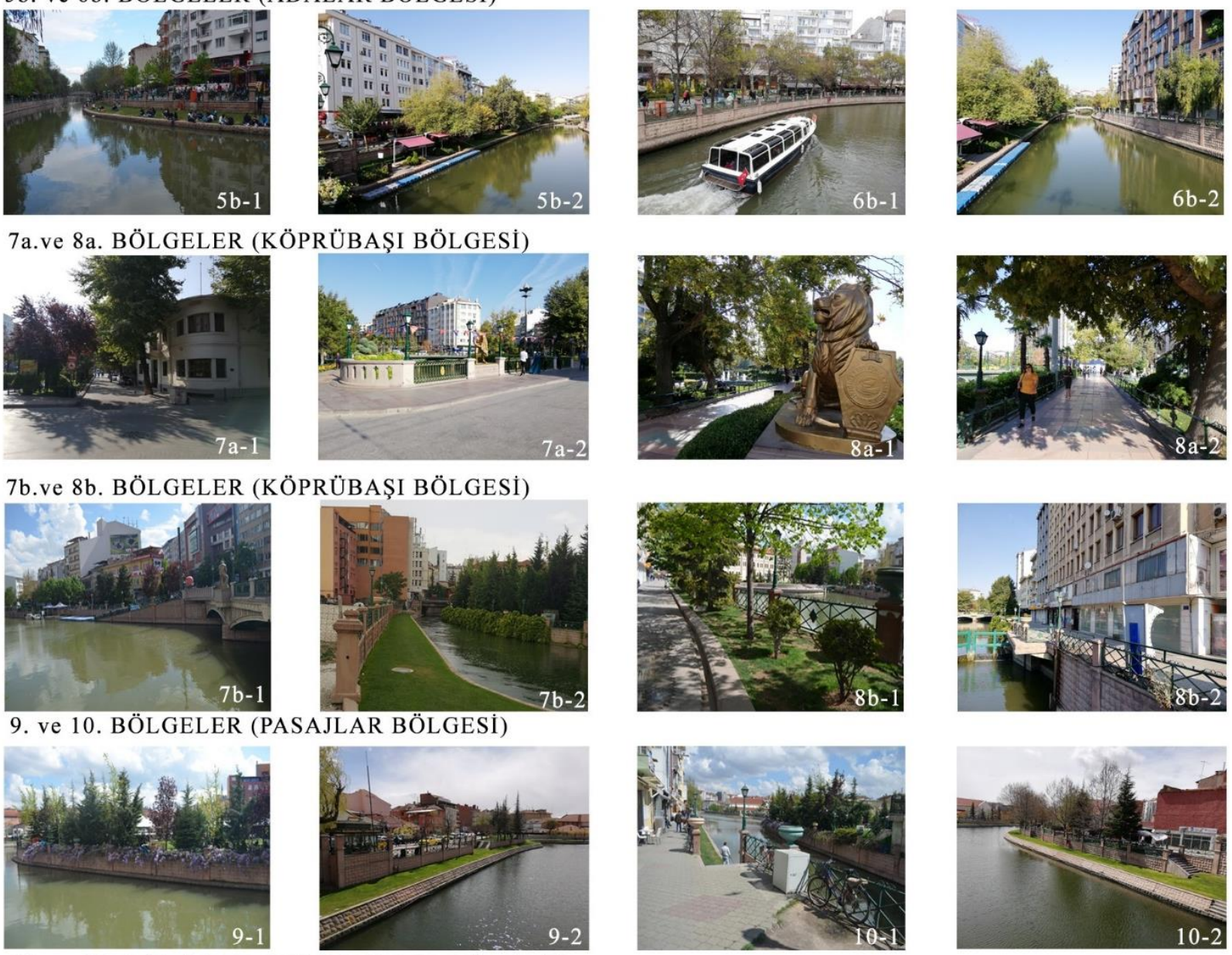

Eskişehir Kenti Porsuk Çayı Kıyısında Mekânsal Örüntü ve Suyla Kurulan Bağlantının Analizi Journal of Urban Academy | Volume: 13 Issue: 3 | ISSN: 2146-9229

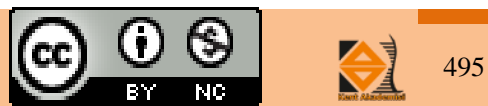




\section{1. ve 12. BÖLGELER (ESKİ OTOGAR BÖLGESİ)}
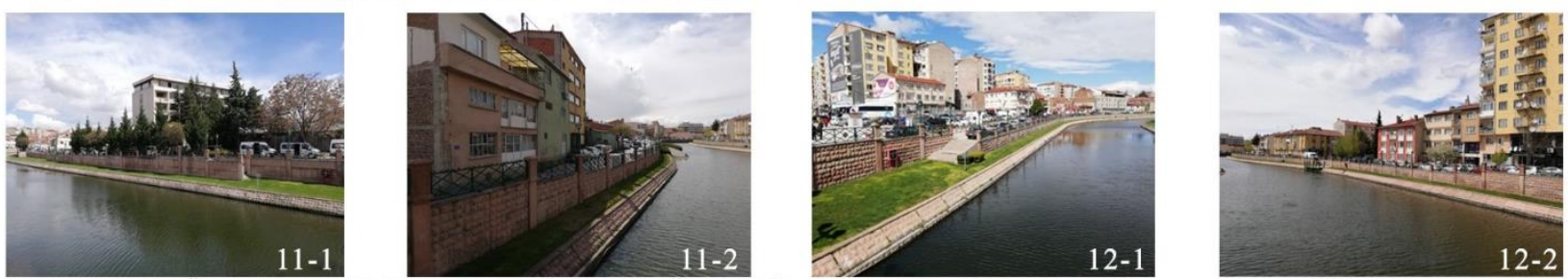

13. ve 14. BÖLGELER (ŞEKER FABRİKASI BÖLGESİ)
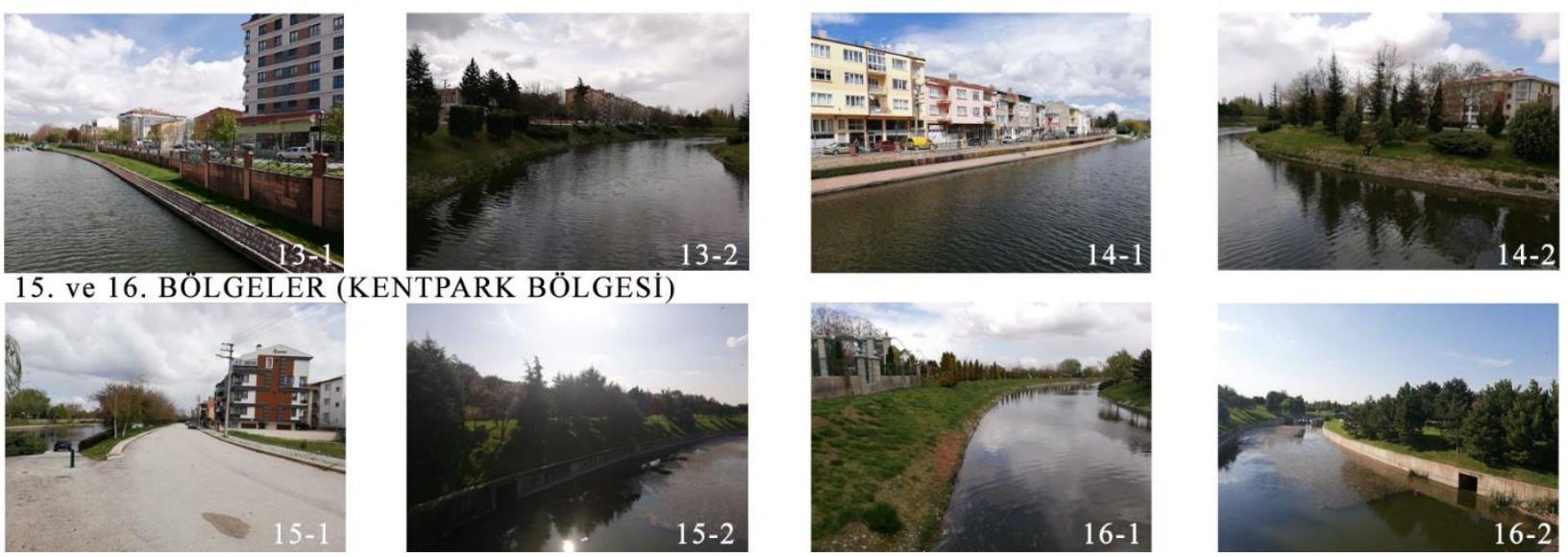

\section{(KENTPARK BÖLGESİ)}
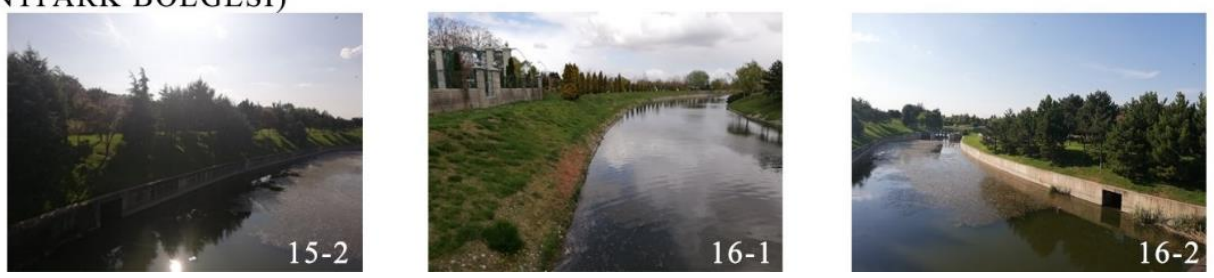

Resim 2. Seri Görünüm Analizi Kapsamında Çalışma Alanı İçinde Porsuk Kıyısında Çekilen Fotoğraflar (Yazarların Kişisel Arşivleri)

\subsection{Belirlenen Bölgeler}

Seri Görünüm Analizi ile belirlenen ve Şekil 2'de sınırları görülen bölgelere isimleri verilirken, Porsuk'un her iki yakasındaki kısımlar bir arada düşünülmüştür. Bölgelerin akarsu ile bölünmüş olması bölge karakteristiğinde kayda değer farklılaşmalara yol açmadığından, karşılıklı kıyıların yer aldığı alanlar tek bir başlık altında alınmıştır. Bölge isimleri, ilgili kent parçasında öne çıkan kent parçalarının isimleri göz önünde bulundurularak belirlenmiştir.

\subsubsection{Kanlıkavak Bölgesi (1. ve 2. Bölgeler)}

Kanlıkavak Bölgesi; Osmangazi (1. Bölge) ile Sümer ve Kırmızıtoprak mahallelerinin (2. Bölge) kıyı bölgelerinin bir bölümünü kapsayan alandır. 2016 yılı itibariyle Odunpazarı Belediyesi tarafından ıslah çalışması yapılan bölgede yaklaşık 1 ha. alana sahip Kanlıkavak Parkı ve karşısında 1,4 ha. alana yayılan Raif Özgür Parkı bulunmaktadır. Parklar, oturma ve dinlenme alanları, çocuk oyun alanları, yürüyüş ve bisiklet yolları ve spor alanlarını bünyesinde barındırmaktadır (Eskişehirliler Kanlıkavak'ta Nefes Alıyor, 2018). Porsuk Çayı üzerine yapılmış olan platformlar sayesinde kentlilerin suya yakınlığı teşvik edilmiştir. Bölge genelinde bakımlı yeşil açıklıklar hakimdir, görüş açıklı̆ı oldukça geniştir ve bölge zengin panoramik görüntüler sunmaktadır (bkz. Resim 3). Her iki bölgenin yeşil alanlarının gerisinde kalan kısımlarda konut yoğunluklu bir yapılaşma vardır. Bölgenin doğu ucunun sınırı; yeşil alan yoğunluğunun azaldığı ve araç trafiğinin başladığı, Vali Ali Fuat Güven Caddesi'nin geçtiği köprü olarak belirlenmiş̧ir. 

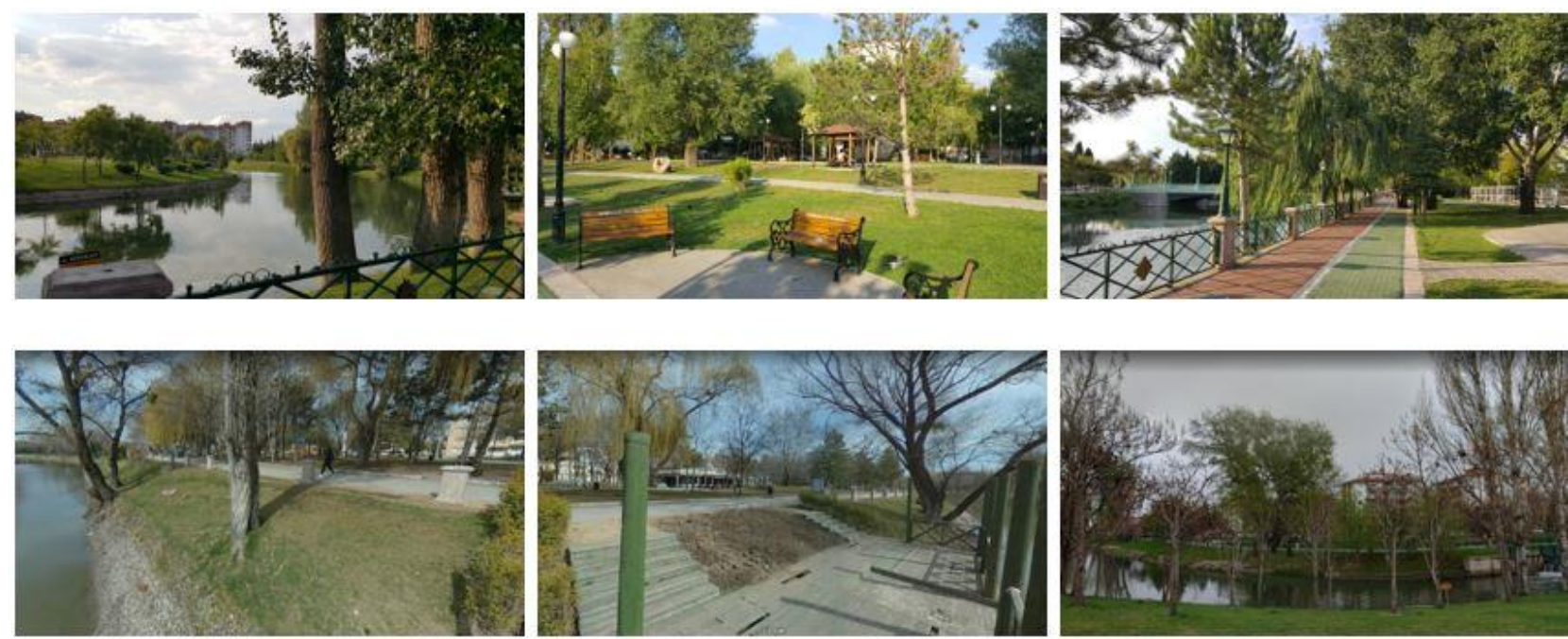

Resim 3. Kanlıkavak Bölgesi’ne Ait Görseller (Yazarların Kişisel Arşivleri)

\subsubsection{Tülomsaş Bölgesi (3. ve 4. Bölgeler)}

Vali Ali Fuat Güven Caddesi ile Atatürk Caddesi arasında kalan bölgedir. 3. Bölge Kırmızıtoprak Mahallesinin bir kısmını içine almakta ve konut dokusunun ağırlıkta olduğu bir yapılaşmayı barındırmaktadır. 4. Bölge ise Tülomsaş yerleşkesi ile sınırlanmaktadır. Her iki bölgede de park ve yürüyüş yolları düzenlenmiş olmakla birlikte, 3 . Bölge araç yolları ve ortalama 4 katlı konutlarla ve 4 . Bölge de fabrikaya ait işletme yapıları ve konutlar ile kesintiye uğramaktadır (bkz. Resim 4). Bir başka deyişle, bu bölgede kıyıda yer alan yeşil açıklıklarda süreklilik esas değildir. Kıyıdaki yeşil alanların hemen arka planında yapılar başlamaktadır. Kıyıda yer alan yapılar bitişik nizam ile ve aynı yükseklikte devam ettiğinden görüş açıklığı kısıtlanmakta ve kuşatılmışlığa neden olmaktadır.
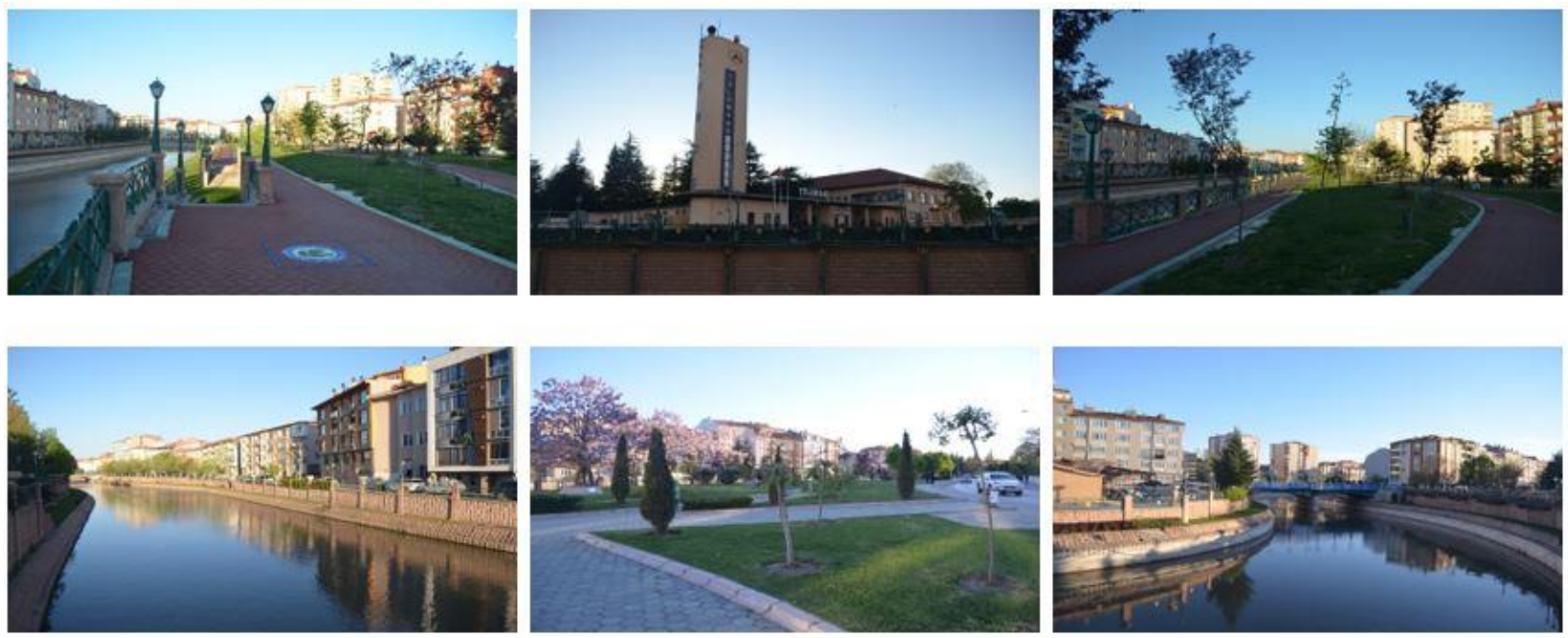

Resim 4. Tülomsaş Bölgesi'ne Ait Görseller (Yazarların Kişisel Arşivleri)

\subsubsection{Adalar Bölgesi (5. ve 6. Bölge)}

5. ve 6. bölge, Kentliler ve turistler tarafından belki de Porsuk kıyısının en yoğun olarak kullanılan bölgeleridir. Bölgenin sınırları belirlenirken araç trafiğinin olmadığı alanlar göz önünde bulundurulmuş ve sınır olarak Atatürk ve Şair Fuzuli caddeleri belirlenmiştir. Bölgeler bitişik nizam apartman tipi konut yapısı yoğunluklu olmalarına rağmen bu yapıların zemin katları ticaret işlevi gören kafe ve market olarak hizmet vermektedir. Adalar Bölgesi içinde yer alan Başarılı Sokak üzerindeki köprünün iki tarafında kafelerin yoğunluğu birbirinden farklı olduğu için dış mekân kullanım yoğunluğu da değişmektedir. Kafe önlerindeki masa ve sandalyelerde vakit geçirme, Porsuk'un seyir 
süresini artırmakta, kıyıda sıralanan 5 katlı arka planın etkisini zayıflatmakta, kuşatılmışlık hissi azalmaktadır (bkz. Resim 5). Bu nedenlerden dolayı bölgeler, kullanım yoğunluğunun değişkenliği göz önünde tutularak 5a, 5b, $6 \mathrm{a}$ ve $6 \mathrm{~b}$ olmak üzere alt bölgelere ayrılmıştır: 5a ve 6a bölgelerinde kafelerin azalması ile konut, park ve açık alan yoğunluğunda artış gözlenmektedir. $6 \mathrm{~b}$ bölgesinde yer alan kafeler, yapı sınırlarının dışına taşarak dış mekânlarında da oturma birimlerine yer verildiği için bölge ayrıştırılmıştır. 5b bölgesi ise daha kapsamlı ticaret işlevli büyük yapıları bünyesinde barındırdığından, kıyıda daha geniş parçalardan oluşmaktadır.

Bu bölgede Porsuk kıyısı boyunca uzanan yeşil alanlar, yine özellikle sıcak aylarda çoğunlukla kentteki öğrenciler tarafından yoğun bir şekilde oturma/dinlenme alanları olarak kullanılmaktadır. Bu alanlar oldukça bakımlıdır ve çay güzergâhı çeşitli panoramik görüntüler ve vistalar sunmaktadır (bkz. Resim 5). Porsuk Çayı'nda tekne ve gondollarla gezi imkânı bulunmaktadır. Eskişehir Büyükşehir Belediyesi (EBB) ve Türkiye Kano Federasyonu tarafindan düzenlenen kano yarışları da su üzerinde gerçekleştirilen bir başka aktivitedir (Gençlik Kupası Kano Yarışları, 2018). $\mathrm{Bu}$ bölgede, aynı zamanda yürüyüş kotundan bir alt kota geniş bir çim set tasarlanarak merdivenlerle erişim imkânı sağlanmıştır.
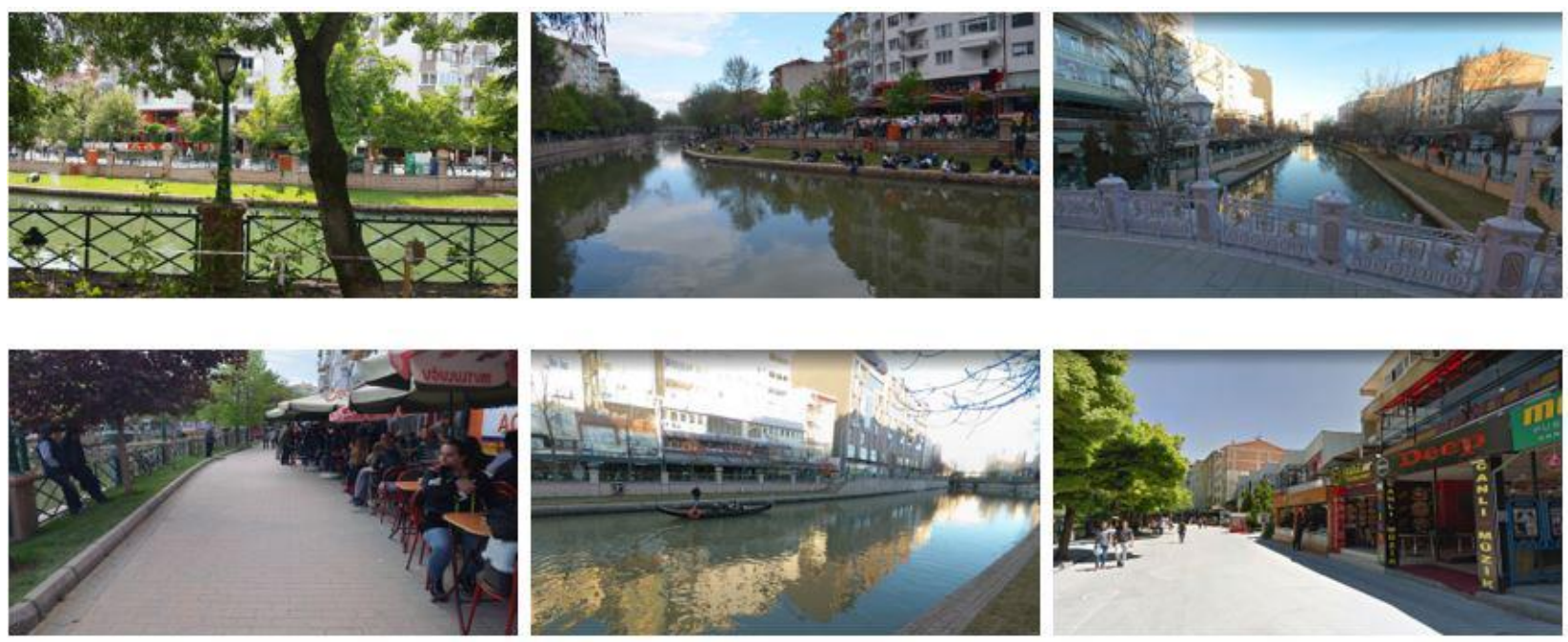

Resim 5. Adalar Bölgesi’ne Ait Görseller (Yazarların Kişisel Arşivleri)

\subsubsection{Köprübaşı Bölgesi (7. ve 8. Bölgeler)}

7. Bölge'nin sınırı, araç trafiğinin yeniden başladığı Şair Fuzuli Caddesi'nin yer aldı̆̆ köprü ile Köprübaşı Caddesi arasında kalan alan olarak belirlenmiştir. Köprübaşı Bölgesinde, Porsuk kıyısının kullanım oranı dolayısıyla yapı yoğunluğu ve yüksekliği diğer bölgelerle kıyaslandığında fazladır. Suyun kuzeyindeki kıyıda yaklaşık 120 metrelik cephesi ile bitişik nizam devam eden dokuda yüksekliğin 8-9 kata kadar çıkması görüş açıklığını daraltmakta ve kuşatılmışlık hissine neden olmaktadır. Bölge; Porsuk Çayı'na paralel Sivrihisar Caddesi'nde yer alan çoğunlukla ticarethanelerin arka cephe kullanımlarıyla şekillenmiştir. 8. Bölge, yaz ve bahar aylarında, Köprübaş1-Kentpark arasında kalan su güzergâhı üzerinde yapılan araç turunun başlangıç noktasını içine almaktadır. Eskişehir Büyükşehir Belediyesi'ne ait Esbot araçlarının (tekneler ve gondollar) durak yeri bu bölgedir (Esbot Seferleri, 2015). Esbot, tekne turlarını yaz ve bahar aylarında Köprübaşı-Kentpark güzergâhında yapmaktadır. Su üzerindeki gezinti imkânı, seyir imkânını artırmakta, görüş açıklığını derinleştirmekte ve oldukça çeşitli vistalar sunmaktadır (bkz. Resim 6). Turların güzergâhı, git-gel ring olarak yaklaşık 7 km'dir. Tepebaşı Belediyesi'nin eskiden bulunduğu ve günümüzde Porsuk Oteli'ne dönüştürülen 3 katlı yapı da akarsuyun üzerinde yer alan adacığın üzerinde konumlandırılmıştır (bkz. resim $6)$.

Kent merkezinde yer alan bu bölgelerin daha ayrıntıda analiz edilebilmesi için alt bölgelere ayrılması uygun görülmüştür. Bunun için Adalar Bölgesi ile Köprübaşı Bölgesi'ni birbirine bağlayan ve yalnızca geçiş amaçlı olarak kullanılan alan 7a ve 8a Bölgesi olarak, diğer kısımlar 7b ve 8b Bölgeleri olarak belirlenmiştir. 

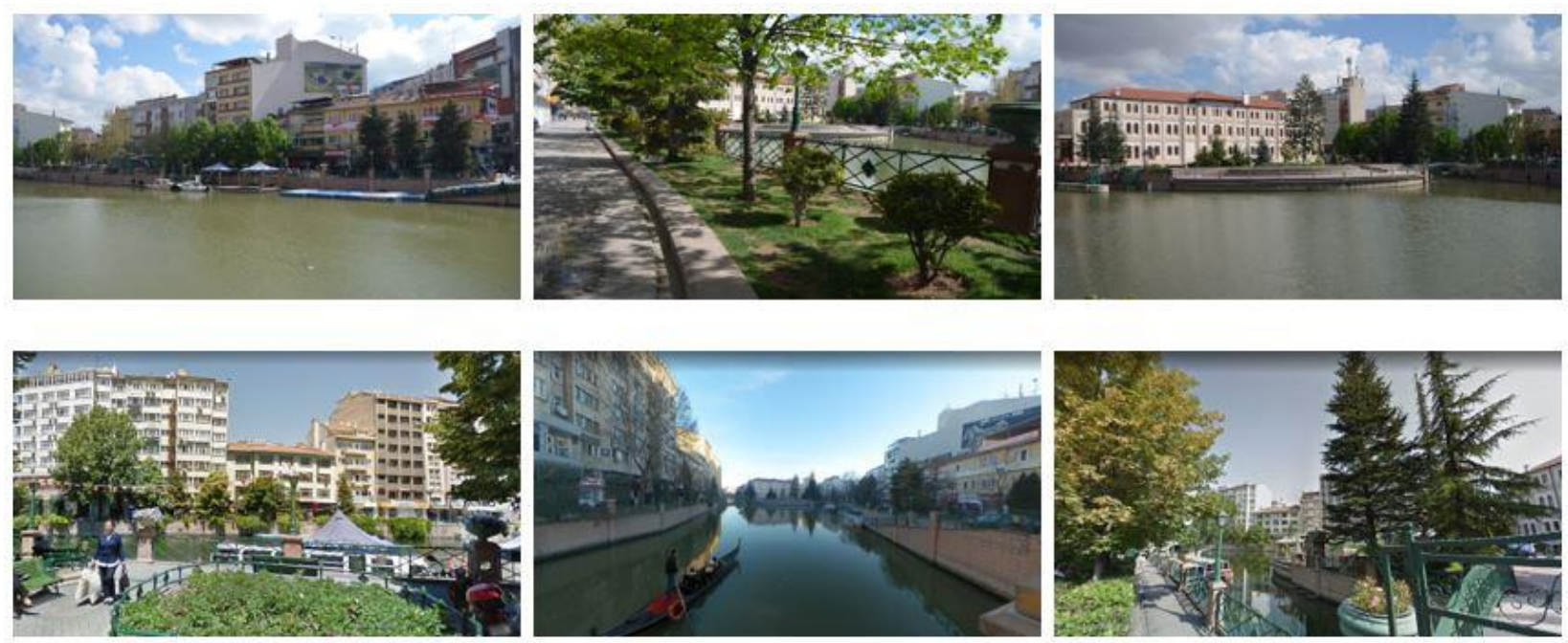

Resim 6. Köprübaşı Bölgesi’ne Ait Görseller (Yazarların Kişisel Arşivleri)

\subsubsection{Pasajlar Bölgesi (9. ve 10. Bölgeler)}

Mustafa Kemal ve Deliklitaş mahallelerinin arasında yer alan bölgelerdir. Bir zamanların en işlek, en gözde alışveriş mekânları olan pasajların birbiri ardına sıralandığı 10. bölge, şehrin büyümesi ve yeni alışveriş mekânlarının oluşmasıyla zamanla yoğun kullanımdan uzaklaşmıştır. Günümüzde ticarethanelerin varlığı devam etse de yapılar onarım görmediğinden yıpranmış durumdadır. Suyun görsel zenginliği ile kıyısındaki yıpranmış yapılar, ön plan-arka plan karşıtlığı doğurmaktadır. Bununla birlikte, pasajların her biri içerisinden zemin kat düzleminde Porsuk'a açılan bağlantıları vardır. $\mathrm{Bu}$ bağlantılar sayesinde kıyı, boylu boyunca pasajlarda yer alan çay ocakları ve benzeri iş yerlerinin dış mekânı olarak kullanılmaktadır. Pasajlardaki bu bağlantılar, ön-plan arka plan ilişkisine katkı sunmakta ve görüş açıklığını artırmaktadır. Adalar bölgesinde karşılaşılan yapı dokusu Yunus Emre Caddesi'nden sonra farklılaşsığından, bu cadde 10. bölge sınırı olarak belirlenmiştir. 10. bölgenin karşı kıyısına denk gelen 9. bölgede, kullanılmayan yapılar ve bu yapıların aralarında kalmış atıl, açık alanlar görülmektedir (bkz. Resim 7).
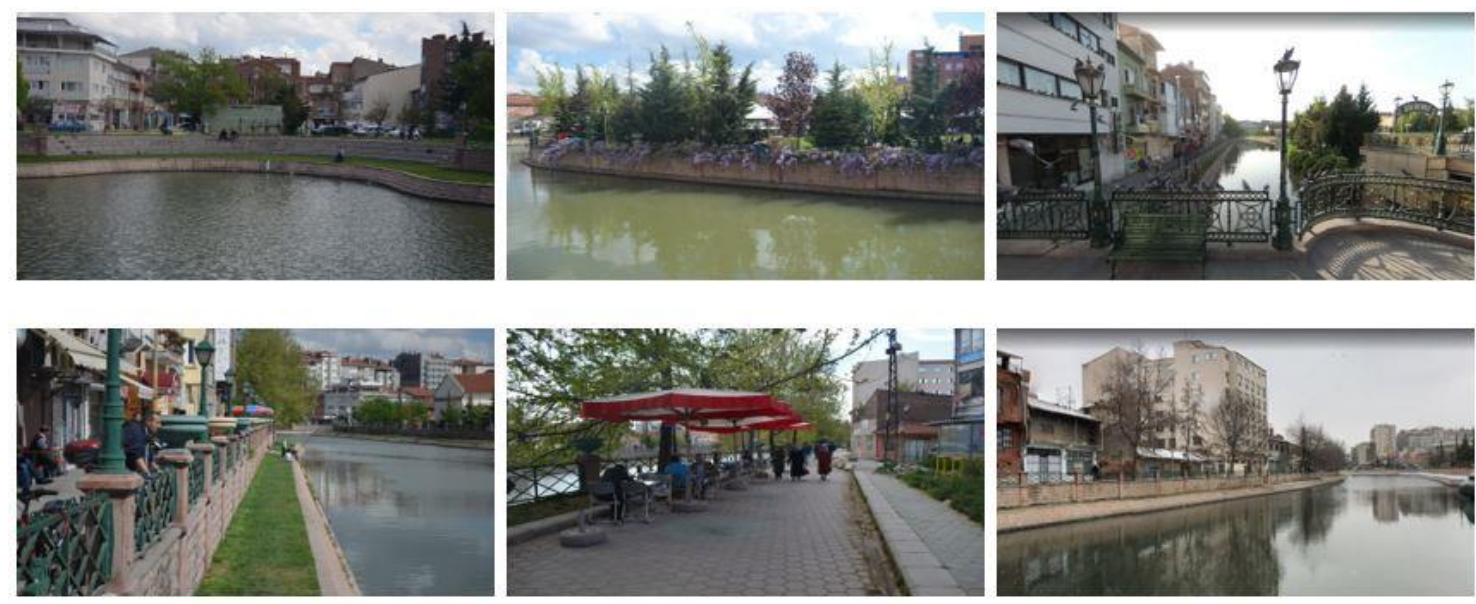

Resim 7. Pasajlar Bölgesi’ne Ait Görseller (Yazarların Kişisel Arşivleri)

\subsubsection{Eski Otogar Bölgesi (11. ve 12. Bölge)}

11. ve 12. bölge, Kurtuluş Mahallesi'nin bir bölümü ile Yeni Mahalle'nin bir bölümünü içermektedir. Her iki bölgenin de sınırları, bir tarafında 1994 yılında Yeni Otobüs Terminali'nin hizmete girmesiyle boşaltılan ve son dönemlerde atıl bir vaziyette bulunan Eski Otogar Binası'na dayanmaktadır. 11. bölge Vatan Caddesi ile son bulurken karşı kıyısındaki 12. Bölgenin sınırı Şeker Fabrikası yerleşkesi başlangıcına kadar uzanmaktadır. Eski otogarın 
kapatılması ile bölge kullanım dışı kalmış ve zaman içinde eski canlılığını yitirmiştir. Bölgedeki kat yüksekliklerinin, batısında kalan bölgelere göre nispeten az olması, zemin-yükseklik yapı farkını azaltmaktadır. Bölgedeki yapı yoğunluğu da görece daha düşük olduğundan, bu durum, genel itibariyle kıyı şeridini kesen daha fazla açıklık sağlamaktadır. Bununla birlikte, yeşil alan ve yapı kullanımlarındaki görece az çeşitlenme, atıl terminal yapısı ve yeşil alanlarda bakımın azalması gibi unsurlar, vistaları kısıtlamaktadır (bkz. Resim 8).
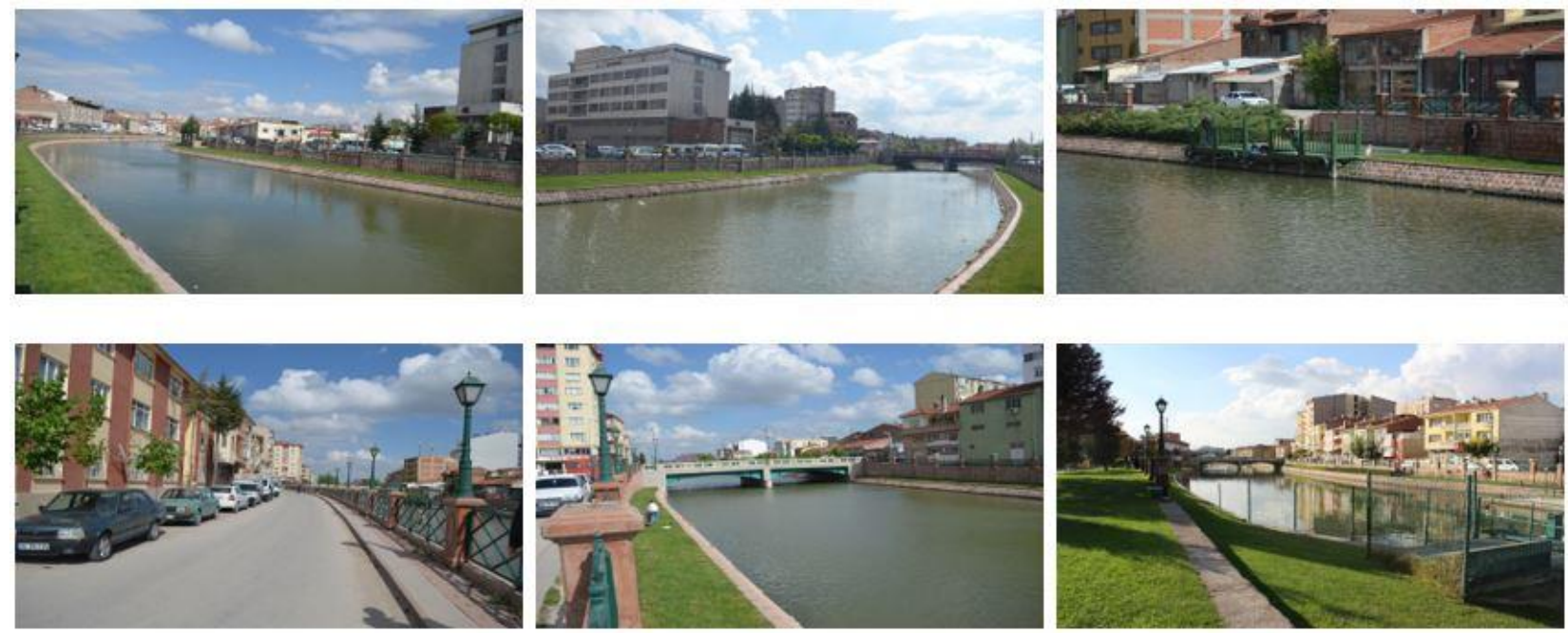

Resim 8. Eski Otogar Bölgesi’ne Ait Görseller (Yazarların Kişisel Arşivleri)

\subsection{7. Ş̧eker Fabrikası Bölgesi (13. ve 14. Bölgeler)}

Gökmeydan ve Kurtuluş mahallelerinin bir kısmını içeren 13. Bölgenin büyük bir parçasını Aydın Arat Parkı kaplamaktadır. Park, oldukça bakımlı ve geniş bir alana sahip olması dolayısıyla panoramik zenginlikler sunmakta ve açıklıklar oluşturmaktadır. Parkın gerisinde kalan konut dokusu ayrık nizam olduğundan açıklı hissi, azalarak da olsa sürmektedir. 14. Bölgede ise Şeker Fabrikası yerleşkesi bulunmaktadır. Eskişehir'in önemli Cumhuriyet dönemi kültür miraslarından kabul edilen Şeker Fabrikası, 1933 yılında işletmeye açılmıştır (Özkut, 2017). O dönemlerde hem ülke ekonomisi için önemli bir yer tutan hem de Eskişehir kentinin sosyo-kültürel gelişiminde katkıları olan fabrika ve konut yerleşkesi, günümüzde halen kullanılmaktadır. Kentsel sit alanı olarak koruma kararı alınan (Eskişehir Merkez Taşınmaz Kültür Varlıkları, 2016) yerleşkenin, Porsuk Çayı tarafında kontrollü ve güvenlikli bir giriş kapısı bulunmaktadır. Bu anlamda bu bölgede suyla kurulabilen tek bağlantı, bir yerleşke ile Porsuk arasındaki kapıdır ve bu bağlantı, yerleşke kullanıcılarına yönelik olması dolayısıyla da kısıtlı bir bağlantıdır. Ön plan-arka plan ilişkileri zayıf kalsa da az yoğun dokusundan dolayı görsel anlamda bir açıklık sunmaktadır ve doğa ile yapılı çevre arasındaki ilişki gözetilmiştir. Her iki bölgede de bakımlı, açık ve yeşil alanlar büyük yer tutmaktadır (bkz. Resim 9). 

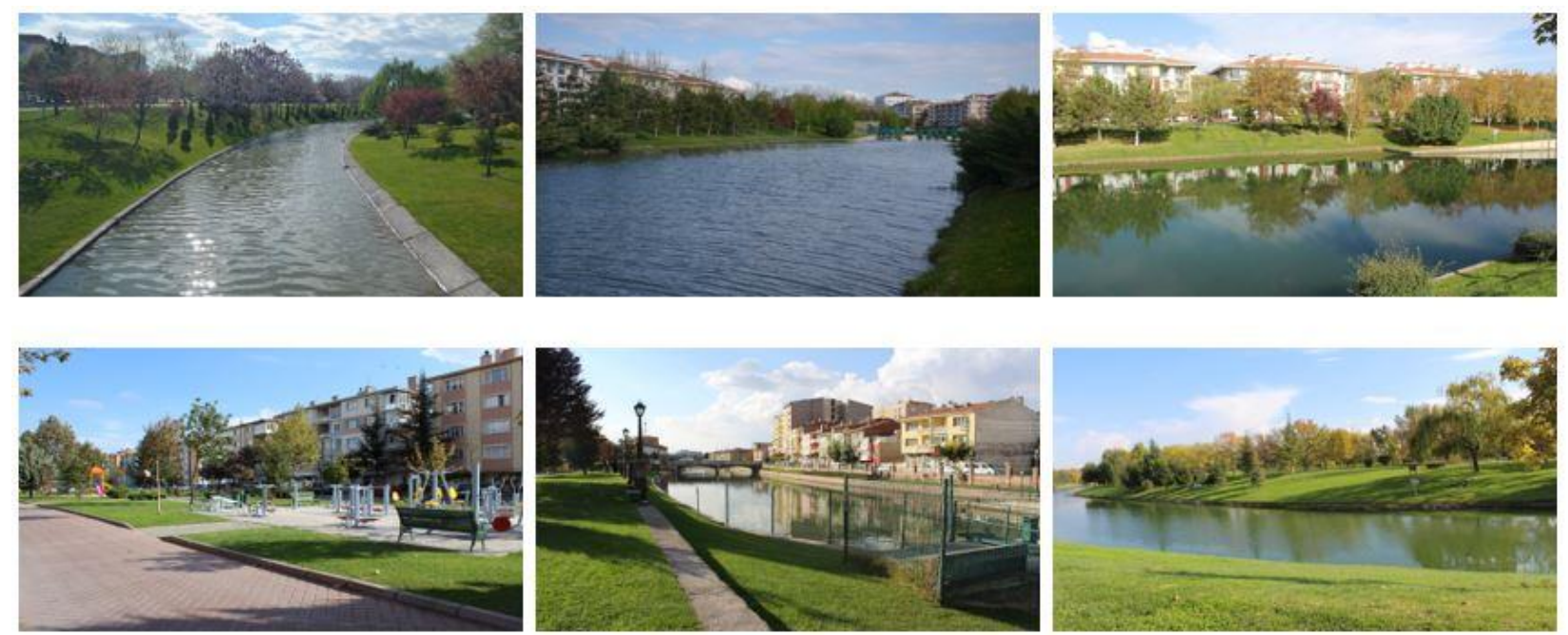

Resim 9. Şeker Fabrikası Bölgesi’ne Ait Görseller (Yazarların Kişisel Arşivleri)

\subsubsection{Kentpark Bölgesi (15. ve 16. Bölgeler)}

Kentpark, Yeni Otogar ile Gökmeydan Mahallesi arasındaki alanda yer almaktadır. Bölgelere de ismini veren ve büyük bir kısmı 16. Bölge sınırları içerisinde kalan Kentpark oldukça bakımlıdır ve içinde açık ve kapalı yüzme havuzları, yapay plaj, restoranlar, at binme alanları, oyun alanları ve yürüyüş yolları bulunmaktadır. Barındırdığı çeşitlilik ile panoramik manzaralar sunan park ile su arasında ön plan-arka plan ilişkisi kuvvetlidir (bkz. Resim 10). Kentpark'ın Porsuk Çayı'na bakan kısmında oluşturulan özel alanda gerçek deniz kumuyla yapay plaj inşa edilmiştir. 16. Bölgede Porsuk'un kenarındaki kullanımı Kentpark oluşturmaktayken; 15. Bölgede, kıyı şeridindeki yeşil sürekliliğin dışındaki hâkim dokunun konut olduğunu söylemek gerekir. Yine de ayrık nizamda bulunan bu yapılar ile Porsuk arasındaki açıklıkların yer yer de olsa sürdüğü görülmektedir. Kıyı şeridindeki yeşil dokudan ve yapıların aralarındaki açıklıklardan dolayı, kuşatılmışlık hissi azdır (bkz. Resim 10).
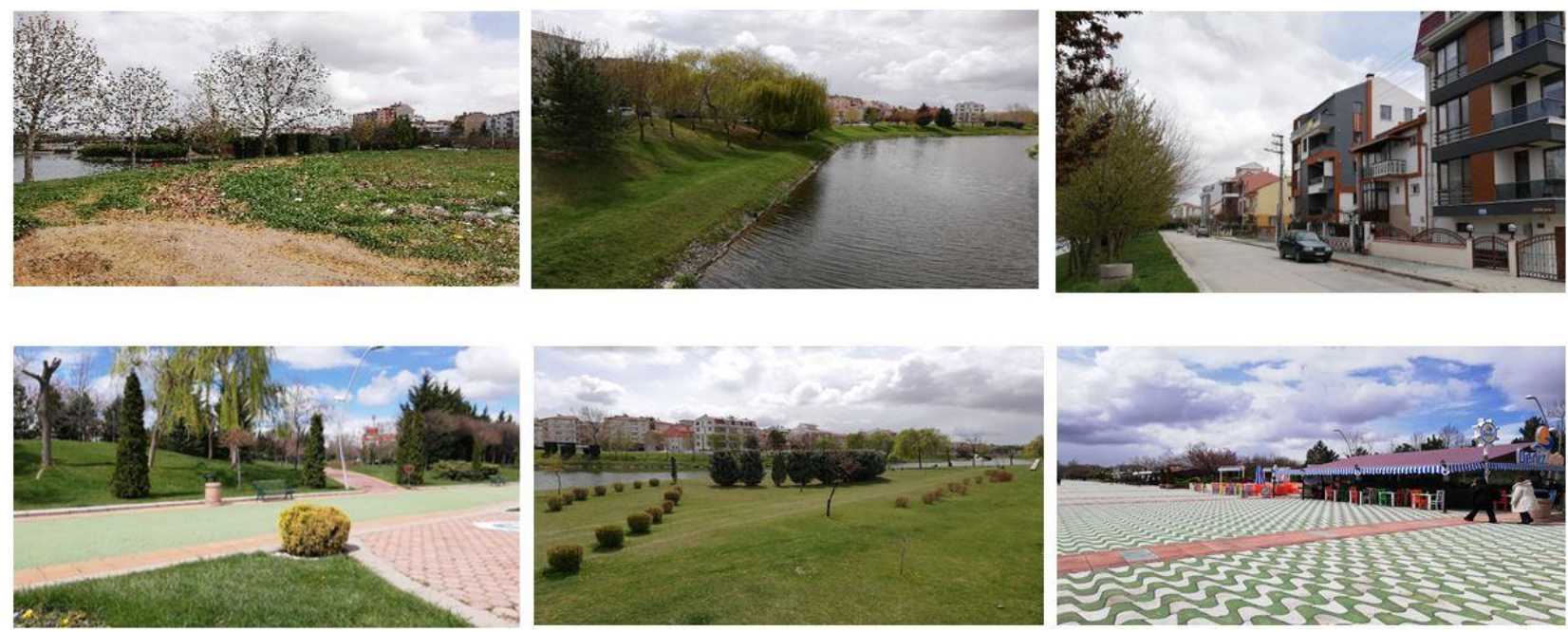

Resim 10. Kentpark Bölgesi’ne Ait Görseller (Yazarların Kişisel Arşivleri)

\subsection{Mekânsal Bağlamda Su ile Kurulan Bağlantı}

Çalışmanın bu adımında, ilk adımda belirlenen her bir bölgede, kullanııının akarsu ile bağlantı kurma yerlerinin ve araçlarının neler olduğu, yine fotoğraflar aracılığı ile saptanmakta ve var olan her bir göstergeye puan verilmektedir 
(bkz. Tablo 2). Kullanıcının akarsu ile bağlantı kurma yerleri; 'içinde', 'üzerinde' ve 'kenarında' olmak üzere 3 temel başlık altında toplanmıştır. 'İçinde', suyun içerisinde yapılabilen aktiviteleri içermekte; 'üzerinde', suya temas etmeden üzerinde olan unsurlara işaret etmekte ve 'kenarında' ise akarsuyun her iki yakasındaki kıyı şeridinde yapılabilen kullanımları kapsamaktadır. Deneyimin yerine dair kategoriler ile aracına dair göstergelerin (tekne, gondol, yaya köprüsü, araç köprüsü, kıyıda bank, kafe/restoran, yaya yolu/bölgesi, meydan, araç yolu, yeşil alan, park, mesire alanı, pencere, balkon, teras vb.) listesine, Tablo 1'de yer verilmektedir.

Tablo 1. Su-Kullanıcı İlişkisine Dair Belirlenen Mekânsal Göstergeler

\begin{tabular}{|l|l|l|l|}
\hline Deneyimin Yeri & İçinde & Üzerinde & Kenarında \\
\hline Deneyim Aracı & İ1: Tekne & Ü1: Yaya köprüsü & K1: Bank \\
& İ2: Gondol & Ü2: Araç köprüsü kaldırım & K2: Yaya yolu \\
& İ3: Kano & Ü3: İskele & K3: Bisiklet yolu \\
& İ4: Yüzme & K4: Kafe/restoran \\
& & K5: Meydan \\
& & K6: Araç yolu- kaldırım \\
& & K7: Park \\
& & K8: Mesire alanı \\
& & K9: Meydan \\
& & K10: Yeşil bant \\
& & \\
& & & \\
& & & \\
& & & \\
& &
\end{tabular}

'Üzerinde' başlığı altında alınan göstergeler arasında, hız faktörü dolayısıyla kullanıcı-su etkileşimine olanak vermemesi bakımından araç köprüleri dahil edilmemiştir. Bu anlamda bu kategoride köprülere yer verilmekle birlikte, yaya köprüleri ve kenarında yaya kaldırımı ya da bisiklet yolu bulunan araç köprüleri dikkate alınmaktadır. Üzerinde kategorisinde köprüler dışında yer verilen diğer bir gösterge iskelelerdir. İskeleler, kullanıcılar tarafından seyir ve dinlenme amaçlı kullanımlarının yanında balık tutma mekânları olarak da seçilebilmektedir.

\subsection{Mekânsal Bağlamda Su ile Kurulan Bağlantıya Dair Bulgular}

Bu bölümde; mahalle sınırları ve seri görünüm analizi yoluyla belirlenmiş olan bölgelerde, kullanıcı deneyimleri değerlendirilmektedir. Su-kullanıcı ilişkisine dair belirlenen mekânsal göstergelerin her bir bölgeye göre tek tek değerlendirilmesi, aşağıdaki matris yoluyla yapılmıştır. Kullanıcının suyla bağlantı kurma araçlarının düzeyleri, bölgede var olan her bir araca 1 puan vermek ve var olmayan deneyimleri boş bırakmak suretiyle ortaya konmaktadır. Matriste her bir bağlantı aracının var olup olmama durumuna göre puan verilmekte ve en son sütunda da genel toplam yer almaktadir. 
Tablo 2. Kullanıcının Porsuk Çayı ile Bağlantı Kurma Yeri, Aracı ve Düzeyini (Toplam Değerini) Gösteren Matris

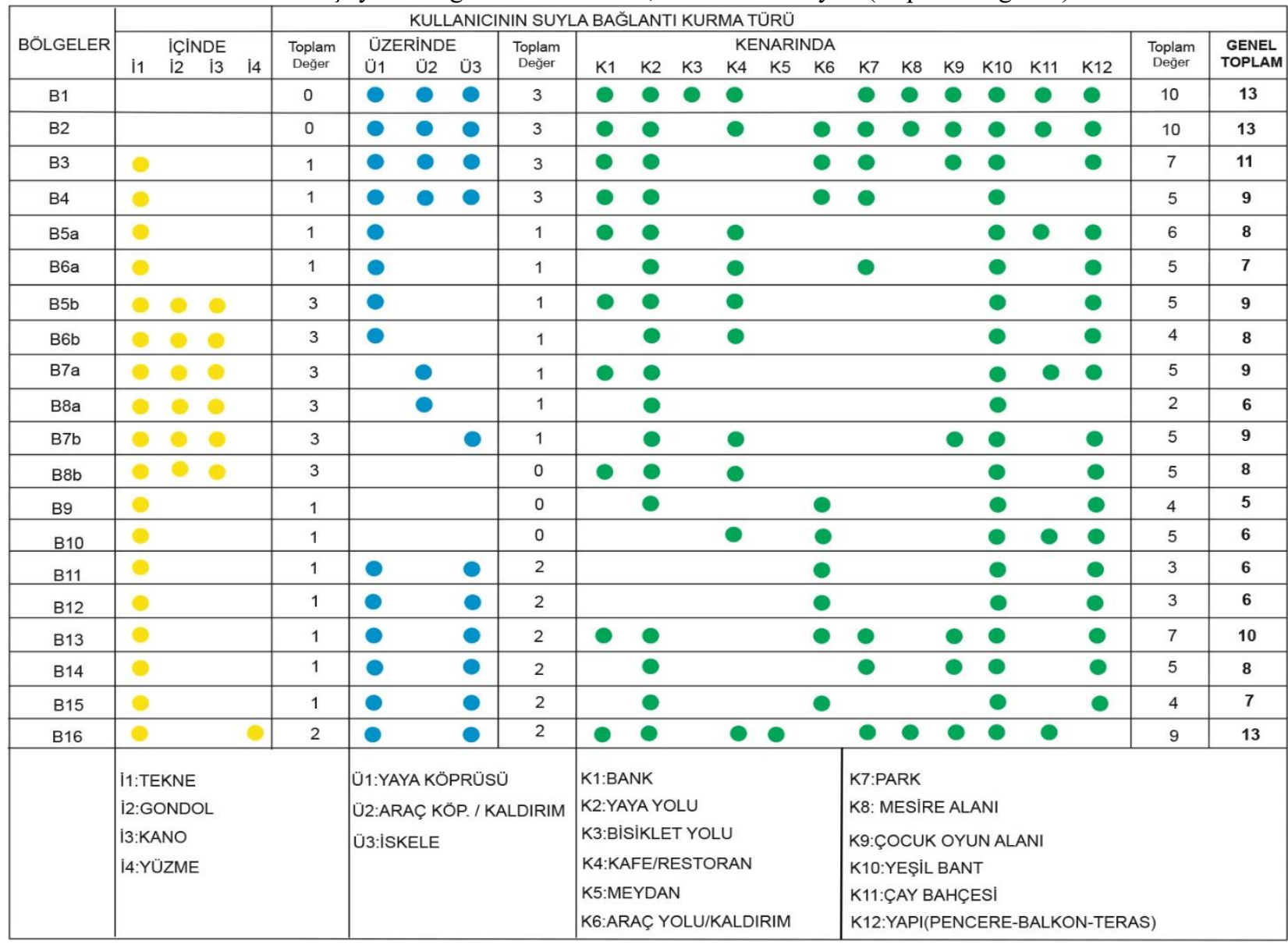

Ortaya çıkan matrise göre, bölgelere tek tek bakıldığında saptanan temel noktalar șu șekildedir:

\subsubsection{Kanlıkavak Bölgesi (1. ve 2. Bölge)}

Kanlıkavak Bölgesi’nde, mekânsal bağlamda suyla bağlantı kurma türü, kenarında ve üzerindeki kullanımlarla oldukça çeşitlidir. Bölgede suyla kullanıcı arasında çok fazla engelin bulunmayışı bu durumun sürekliliğini sağlamaktadır. Ayrıca diğer bölgelerde rastlanmayan bisiklet yollarının varlığı bölgedeki etkileşimi çeşitlendirmektedir. Bu anlamda, 1. ve 2. bölgelerin kıyı kullanımının en yoğun olduğu bölgeler olduğu söylenebilir. Bölgedeki köprü ve iskelelerin varlığı da kullanıcının akarsu ile olan etkileşim düzeyini artırmaktadır. 
Tablo 3. Kanlıkavak Bölgesi'ne (1. ve 2. Bölge) Ait Matris

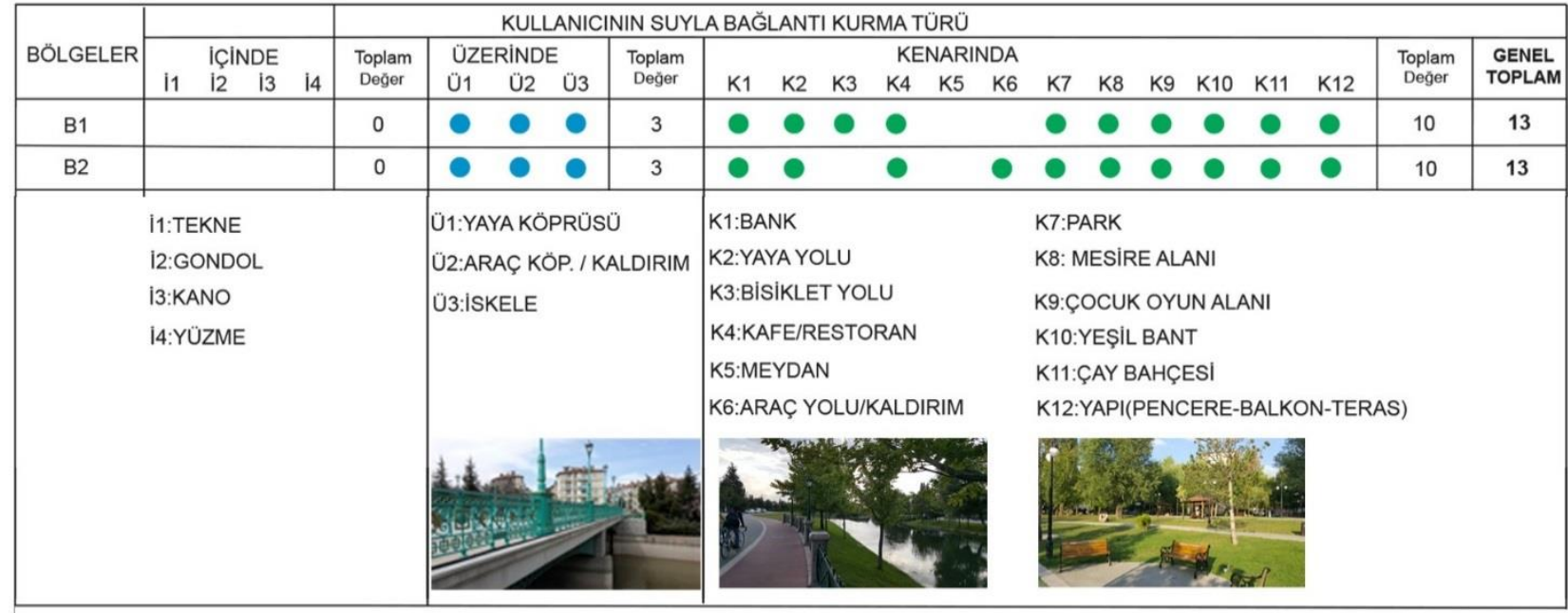

\subsubsection{Tülomsaş Bölgesi (3 ve 4. Bölge)}

Tülomsaş Bölgesinde; araç yolları, araç köprüleri ve konut kullanımının akarsuyun kullanımına dahil olmasıyla birlikte, kullanıcı kıyı bölgelerden kısmen uzaklaşmaktadır. Ancak yine de parklar, çocuk oyun alanları ve kuvvetli yeşil bandın varlığı ile ilişki sürdürülmektedir. Kullanıcının, Kanlıkavak Bölgesi’nden devraldığı akarsu üzerinde ve kenarında kurduğu bağlant1, 3. ve 4. Bölgelerde de devam etmektedir.

Tablo 4. Tülomsaş Bölgesi'ne (3. ve 4. Bölge) Ait Matris

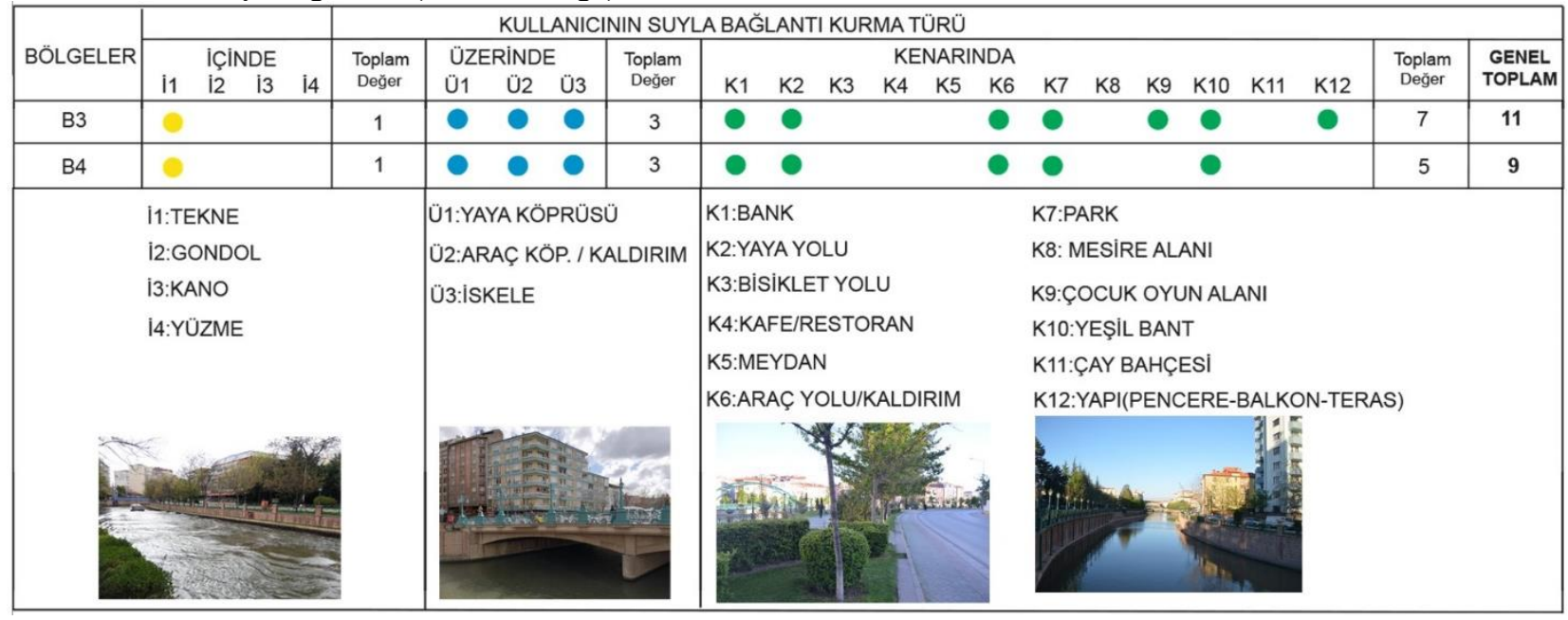

\subsubsection{Adalar Bölgesi (5. ve 6. Bölge)}

Porsuk Çayı kenarı, özellikle merkez içinden geçen kısmında kentin çok sayıda dinlenme yeri, kafe ve restoran gelişimini barındırmaktadır. Porsuk kenarına yerleştirilmiş olan kilitli demir parmaklıklar dolayısıyla kıyıya erişim kontrollüdür. Ancak bu durum, 5. ve 6. Bölgeleri tanımlayan Adalar Bölgesi'nin, Porsuk'un en yoğun olarak kullanıldığı bölgeler olmasına engel olamamaktadır. Bu bölgelerin en göze çarpan özelliği, akarsuyun burada en yoğun biçimde, 'kenarında' bağlantıya olanak tanıması olmuştur. Ayrıca Adalar Bölgesi, kullanıcıların akarsu 
deneyimini köprüler aracılığıyla 'üzerinde' en yoğun olarak yaşadığı bölgedir. Bu bölgede sık yer verilmiş olan köprüler, kullanıcıların her iki kıyıya erişimini sağlarken aynı zamanda sundukları kent vistalarıyla kentli ve turistler tarafından fotoğraf çekimi için yoğun şekilde kullanılmaktadır (bkz. Tablo 5).

Tablo 5. Adalar Bölgesi'ne (5. ve 6. Bölge) Ait Matris

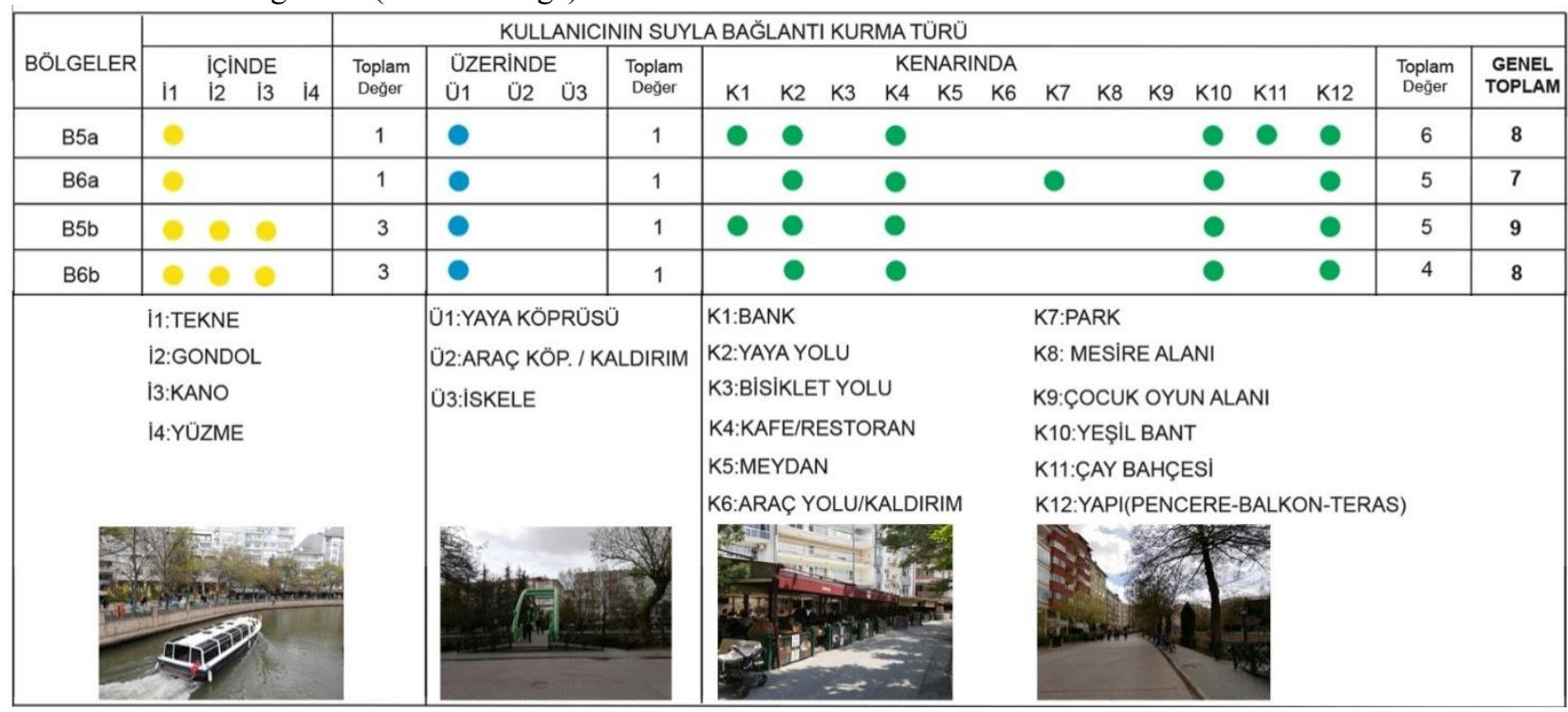

\subsubsection{Köprübaşı Bölgesi (7. ve 8. Bölge)}

Adalar Bölgesi'nin sonlanması ile beraber kafe/restoran varlığı da bitmekte, Köprübaşı bölgesinde -kenarlardaki kilitli parmaklıklar kaldırılmasına rağmen- kıyı kullanımı azalmaktadır. Su ile kullanıcı arasındaki bağlantı sürekli olmamakla birlikte 'kenarında' kurulmaya devam etmektedir (bkz. Tablo 6).

Tablo 6. Köprübaşı Bölgesi'ne (7. ve 8. Bölge) Ait Matris

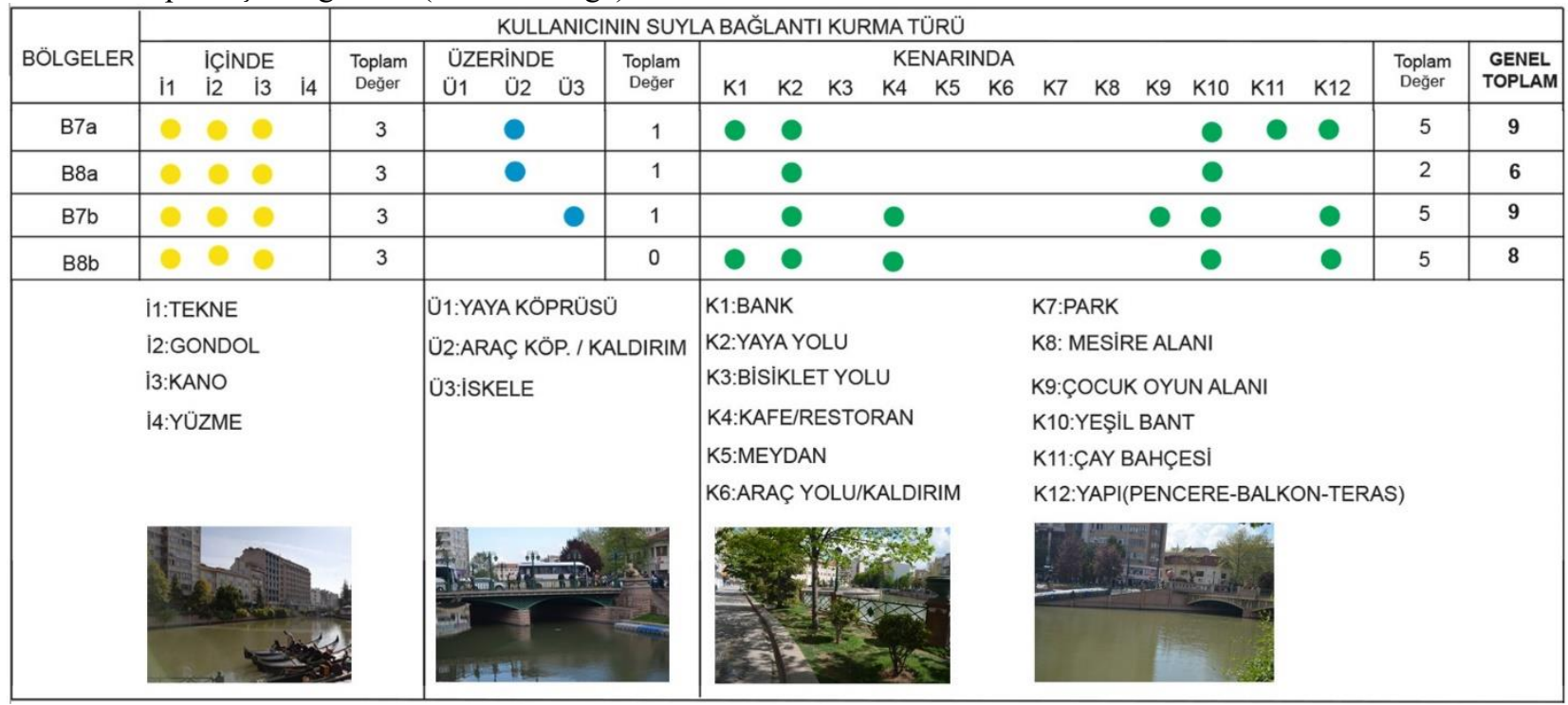




\subsubsection{Pasajlar Bölgesi (9. ve 10. Bölge)}

Pasajlar Bölgesinde, Porsuk kenarındaki ilişki; 10. Bölgede yer alan pasajların içerisindeki çayhanelerin kıyıya taşmaları nedeniyle, yeniden güçlenmektedir. Ancak akarsuyun üzerindeki kullanımlar açısından değer 0'dır ve akarsu içindeki kullanım ise neredeyse yok düzeydedir (bkz. Tablo 7).

Tablo 7. Pasajlar Bölgesi'ne (9. ve 10. Bölge) Ait Matris

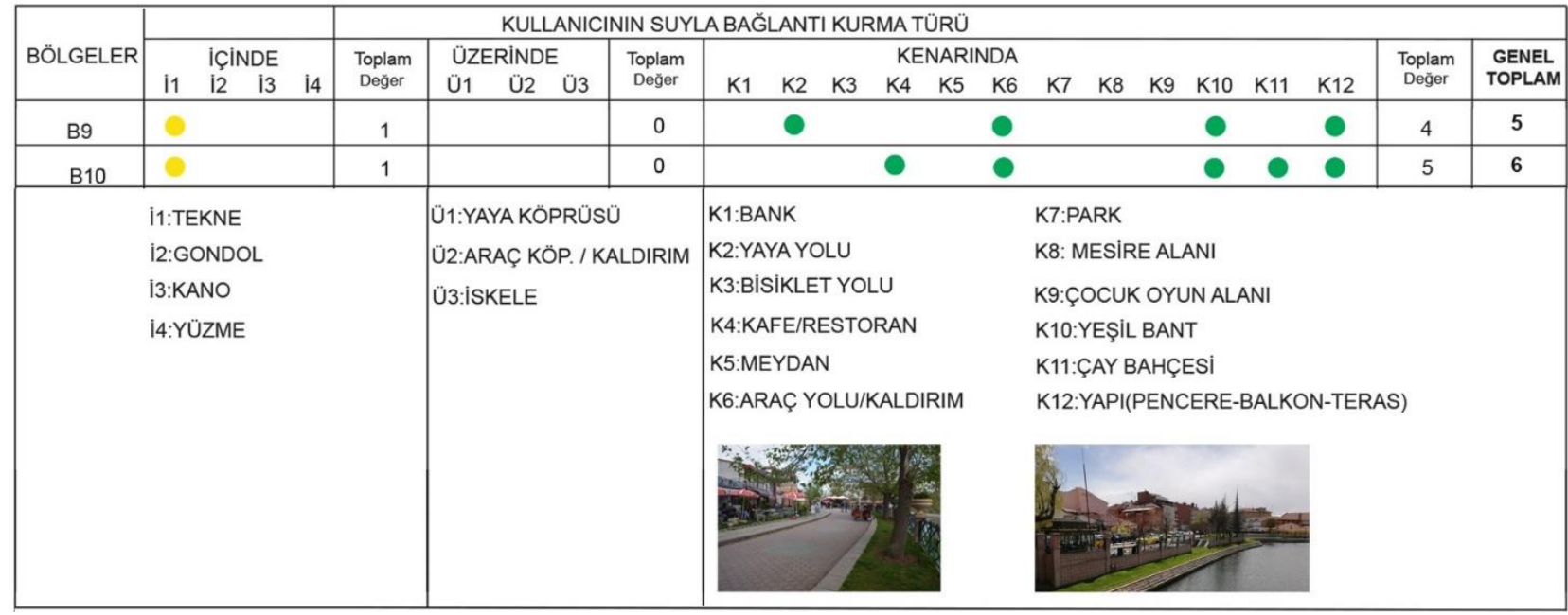

\subsubsection{Eski Otogar Bölgesi (11 ve 12. Bölge)}

Eski Otogar Bölgesi'nde, kullanıcı Porsuk kenarından iyice koparılmıştır. 11. ve 12. Bölgelerde yaya yürüyüş yollarının bulunmaması, bu durumun ortaya çıkmasındaki en büyük etken olarak görülebilir. Ancak daha önce de vurgulanan yeşil bant varlığı ile Porsuk kıyısı kısıtlı da olsa kullanılmaya devam etmektedir. Kent içerisinde belki de Porsuk'un en çok görmezden gelindiği ve atıl kaldığı bölgenin bu bölge olduğu ifade edilebilir (bkz. Tablo 8).

Tablo 8. Eski Otogar Bölgesi'ne (11. ve 12. Bölgeler) Ait Matris

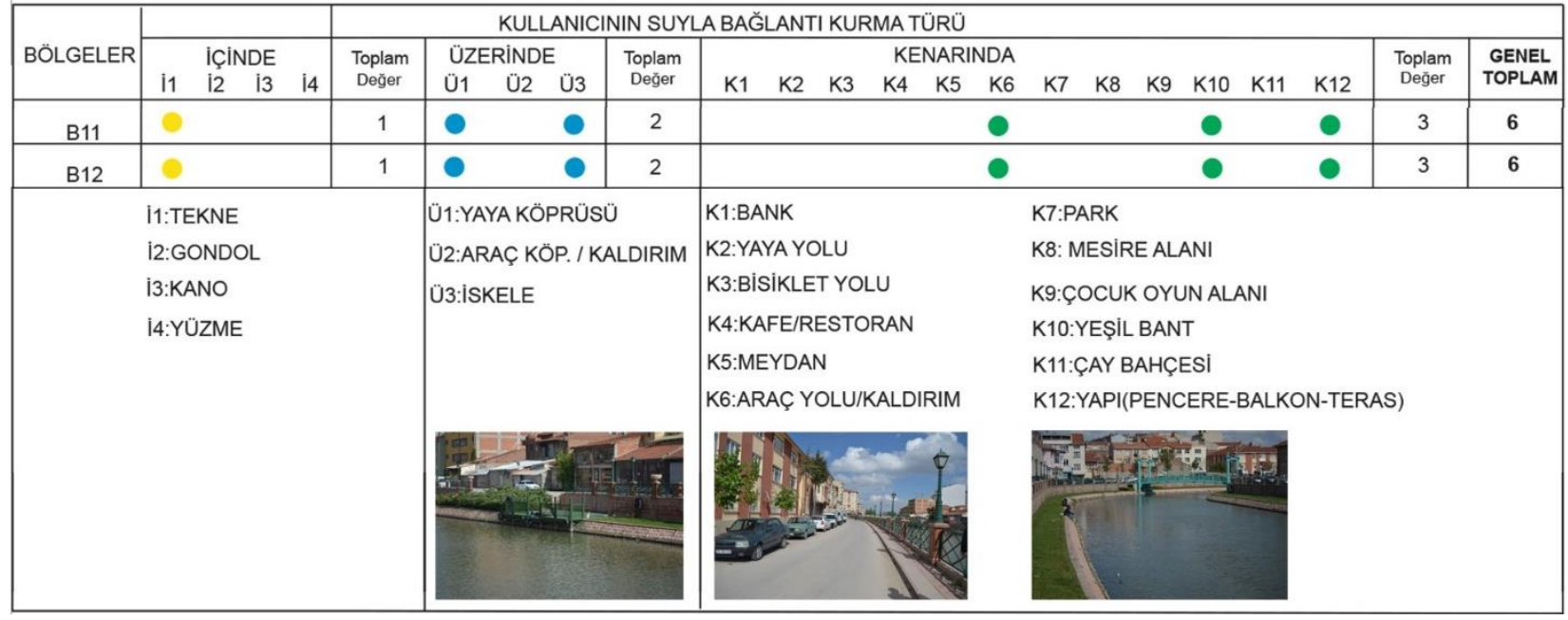




\subsection{7. Şeker Fabrikası Bölgesi (13. ve 14. Bölge)}

Bir önceki bölgede tespit edilen kullanım azlığı, Şeker Fabrikası Bölgesi’nin varlı̆ğ ile birlikte kayda değer bir dönüşüm göstermektedir. Her ne kadar 14. bölgenin fabrika yerleşkesi olarak kullanımına devam edilmesi sebebiyle bölge çoğunlukla yerleşke sakinleri tarafından kullanıma açık olsa da 13. bölgede yapılan kıyı düzenlemesi sayesinde akarsu ile kenarında bağlantı kurma çeşitliliği bu bölgede artış göstermektedir (bkz. Tablo 9).

Tablo 9. Şeker Fabrikası Bölgesi’ne (13. ve 14. Bölgelere) Ait Matris

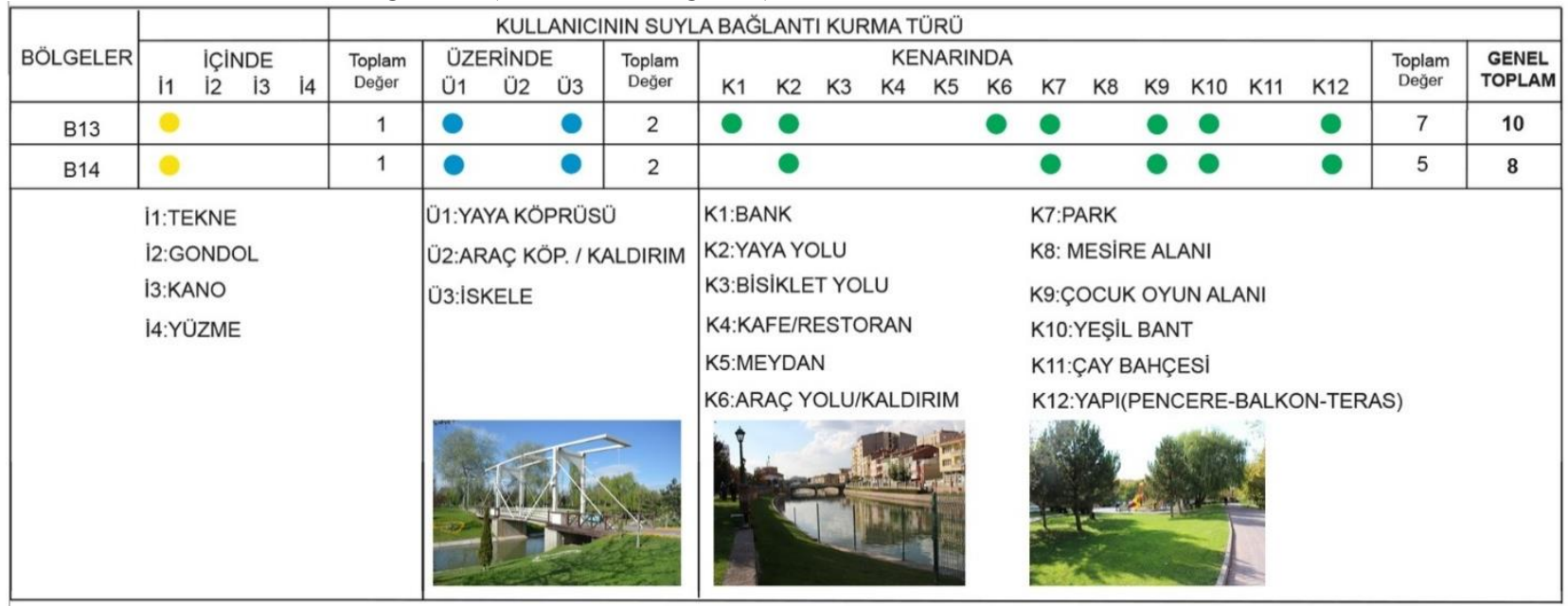

\subsubsection{Kentpark Bölgesi (15. ve 16. Bölge)}

Kentpark Bölgesi, kent çeperinde yer alan bölgeler olarak değerlendirmeye alınmıştır. Yerel yönetim tarafından kapsamlı bir rekreasyon alanı olarak tasarlanan 16. Bölgedeki Kentpark, su ile kullanıcı iletişiminin sınırlarının bu bölgelere kadar genişlemesine sebep olmuştur. Kentpark içerisinde yer alan yapay plaj sayesinde Porsuk, bölgeler arasında ilk ve tek olarak bu bölgede yüzme eylemine olanak tanıması ile akarsuyla 'içinde' kurulan bağlantıyı kuvvetlendirmiştir (bkz. Tablo 10).

Tablo 10. Kentpark Bölgesi’ne (15. ve 16. Bölgeler) Ait Matris 


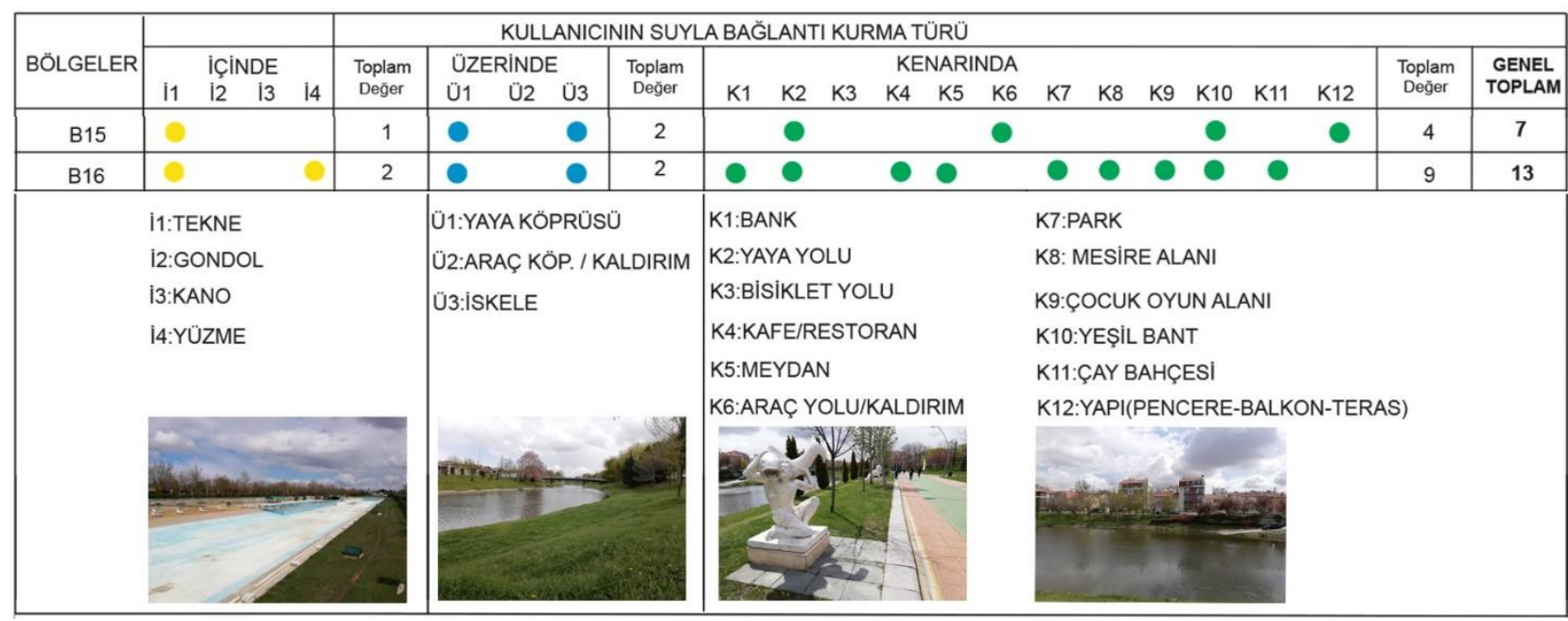

Bölgelere ait matrislerde ortaya çıkan puanların genel bir değerlendirmesi yapıldığında:

Çeperlerde yer alan 1, 2 ve 16 numaralı bölgeler 13 puan alarak kullanıcının su ile bağlantı kurma türlerinin en çok çeşitlilik gösterdiği, bir başka ifade ile akarsu kent etkileşim potansiyelinin en yüksek olduğu bölgeler olarak tespit edilmiştir. Kanlıkavak Parkı ve Kentpark'ı içerisine alan bu bölgelerde kullanıcının akarsu ile bağlantı kurma aracı çeşitlenmektedir. Kanlıkavak Bölgesi'nde Porsuk'un her iki kıyısı benzer sonuç üretse de Kentpark’ta durum biraz farklıdır. 15. Bölge'de park sınırları dışında kalan alanlarda yer alan yoğun yapılaşma, akarsu-kentli etkileşimini azaltmıştır. 15. Bölge'nin 7 puan alması, bu durumun bir göstergesidir.

1 ve 2 numaralı Kanlıkavak Bölgesi'ndeki etkileşim, çeperler ve merkez arasında kalan bölgelerden 11 puan alan 3 ve 9 puan alan 4 numaralı Tülomsaş Bölgesi'nde, kısmen azalarak da olsa devam etmektedir. Tülomsaş Bölgesi'ndeki benzer durum, 13 ve 14 numaralı Şeker Fabrikası Bölgesi’nde de söz konusudur. 8-10 puan alan bu bölgelerde Şeker Fabrikası yerleşkesinin, dışa kapalı yapısı sebebiyle yerleşke dışındaki kullanıcıların erişimine olanak tanımıyor olduğu göz önünde bulundurulmalıdır.

Kent merkezini çevreleyen ve Kentpark'a yakın konumda bulunan 11 ve 12 numaralı Eski Otogar Bölgesinde, akarsu ve kullanıcı etkileşiminin 6 puana düşerek en gerilerde kaldığı görülmüştür. Benzer biçimde, 9 ve 10 numaralı Pasajlar Bölgesinde de kullanım düzeyine ait değer 5 ve 6 puandır. Kent merkezinde ise sonuç ortalamaya yakın değerlerde çıkmıştır. Özellikle 5 ve 6 numaralı Adalar Bölgesi ile 7 ve 8 numaralı Köprübaşı Bölgesi'nde puanlar 6-9 arasında kalmıştır. Kentlinin ve turistin en çok tercih ettiği alanlar olarak karşımıza çıkan bu bölgelerde akarsuya erişimin kontrollü (görevliler aracılığıyla ve kilitli kapılar ile) sağlanması sebebiyle tabloda yer alan puanlar ortalamanın üzerine çıkamamıştır.

Elde edilen bulgular göstermektedir ki; Porsuk Çayı'nın kent içinde kalan kıyı şeridinde, Pasajlar ve Eski Otogar bölgeleri olumsuz anlamda ayrışmaktadır. Diğer bölgelerin en azından 'kenarında' kullanıma olanak sağlamakta olduğu görülmektedir. 'İçinde' kullanım yerinin aldığı puanlara bakıldı̆̆ında, Kentpark Bölgesi 3 tam puan ile öne çıktığı görülmektedir. Eskişehir Büyükşsehir Belediyesi'nin yapmış olduğu yapay plajın Kentpark'ta bulunması, bu etkileşimi güçlendirmiştir. Adalar ve Köprübaşı Bölgeleri de gondol ve bot seferlerinin yoğun olarak yapıldığı bölgeler olmaları sebebiyle 'içinde' deneyimini yaşatma yönleriyle benzeşmektedir. Yaya ve araç köprüleri ile iskelelerin varlığı ve aktif kullanımları ile Kanlıkavak ve Tülomsaş bölgelerinde, diğer bölgelere göre 'üzerinde' deneyimi daha yoğun yaşanmaktadır. Özellikle Adalar ve Pasajlar bölgelerinin kıyılarında yer alan kafe ve restoranlar, akarsu ile 'kenarında' kurulan bağlantı biçimini güçlendirmektedir. Porsuk çevresindeki yeşil alanlar ve yürüyüş yolları, kullanıcıyı akarsu kenarına doğru çekmektedir. Merkezde yapılı çevre yönüne doğru bir eğilime bağlı olarak akarsu ile kullanıcı bağlantısının zayıf kalması beklense de özellikle, Adalar, Köprübaşı ve Pasajlar bölgelerinde Porsuk Çayı kıyısı boyunca yeşil bandın ve yaya akslarının sürekliliğinin korunmuş olması olumlu yönlerdir. 


\section{TARTIŞMA VE SONUÇ:}

Kentsel akarsular, özellikle de kentin içerisinden çapsal olarak kenti ikiye bölerek geçenler, tüm diğer etkileşimlerle birlikte, kentin mekânsal örüntüsünü etkilemekte ve ondan etkilenmektedirler. İçerisinden akarsu geçen pek çok kentte, su kıyısı ve yakın çevresinde kentsel kullanımlar çeşitlenmektedir. Kıyı boyu ya da karşılıklı iki kıyıdaki kullanımlar, kentlinin suyla bağlantılı deneyimlerinin düzeyine yansımaktadır. Kıyı boyunca kimi bölgelerde kullanımların çeşitliliği artmakta ve deneyim zenginleşmekte, kimi bölgelerde kullanım çeşitliliği azalmakta ve deneyim düzeyi düşmektedir. Akarsu kıyısını içeren kent parçalarında izlenen mekânsal örüntü ve su ile kullanıcı arasındaki bağlantıya dair araçlar birlikte değerlendirildiğinde, akarsu kıyısı ve kentin bütünleşme düzeyi hakkında ipuçları veren bulgulara ulaşılabilmektedir. Daha önce Türkiye'de bu kapsamda bir çalışmanın yürütülmemiş olması, araştırmanın özgün yönünü oluşturmaktadır.

Kentsel akarsular, çok sayıda kentsel olgu ile etkileşim halinde olmakla birlikte, bu çalışma kapsamında suyun yakın çevresi ile olan bağlantısı üzerinden, mekânsal bağlamda bir değerlendirmeye odaklanılmıştır. Çalışmada, kullanıcının suyla bağlantı kurma yerlerinin akarsuya göre olan konumları temel alınarak; akarsuyun içinde, üzerinde ya da kenarında yer alan araçlar üzerinden değerlendirilmektedir. Bu araçların oluşturduğu göstergelerin varlığının tespiti ile çalışma alanındaki bölgelere göre Porsuk'un kent ile etkileşim yeri, aracı ve düzeyinin değişkenlik gösterdiği dikkat çekmektedir. $\mathrm{Bu}$ durum ise belli bölgelerde tersi olsa da,kentin geneli değerlendirildiğinde Porsuk'un kentli ile dengeli ve sürekli bir etkileşim içinde olamadığını göstermektedir. Bundaki temel nedenler arasında, kıyıdaki yaya mekânları hatta kent mobilyası düzeyindeki alt ölçek araçların yanı sıra, üst ölçekte kıyıdaki kentsel alan kullanımlarında ağılıklı olarak yapılı çevre lehinde kararlar üretilmiş olmasının bulunduğu görülmektedir. Oysa kentsel akarsular söz konusu olduğunda dahi, doğa ile yapılı çevreyi bütünleştiren yaklaşımlar göz ardı edilmemelidir. Porsuk Çayı ile kent ilişkisinin güçlendirilebilmesi, akarsuyun kıyısında su ve kent arasındaki bağlantının sürekliliğinin gözetildiği türden müdahaleleri gerekli kılmaktadır. Bununla birlikte kıyıda, uzun vadede park, çay bahçesi, mesire alanı gibi yeşil alanlara yer ayrılabilmesi; imar haklarına dair yasal, yönetsel ve uygulama boyutunda radikal düzenlemeleri gerekli kılmaktadır. Yeşil alanlar, akarsu-kıyı arasındaki bağlantı araçlarını yoğun biçimde barındırabilmeleriyle, etkileşim düzeyinde öne çıkmakla birlikte, kısa vadede bu alanlara olanak veren büyük açıklıkların tasarlanması mümkün olmayan kent parçalarında, diğer kullanım araçlarına münferit olarak yer verilmesi de, kentli-su ilişkisini destekleyecek bir alternatif sunmaktadır. Bu bağlamda, örneğin; Pasajlar ve Eski Otogar bölgeleri gibi etkileşim düzeyinin düşük olduğu kent parçalarında geliştirilecek projelere, kullanıc1 ile akarsu arasındaki etkileşimi artıracak araçların eklenmesi gündeme getirilebilir.

Porsuk Çayı, parklar, büyük kentsel alanlara sahip işletmelerin yer aldığı kent parçaları ve nispeten kent merkezi yakın çevresi dışında kalan bölgelerde, yapılı çevre içerisinde pasif bir eleman olarak seyretmekte ve kullanıcı deneyimleri kısıtlı kalmaktadır. Porsuk kenarında, yer yer parklar ve yeşil şeritler bulunmakla birlikte, kıyı boyu bir yeşil sistem sürekliliği bulunmamaktadır. Porsuk ve kenarındaki müdahaleler, kent genelinde olmasa da kentin belli bölgeleri için, ülkemiz kentleri arasında başarılı örnekler olarak öne çıkmakla birlikte, planlama ve tasarım geleneği bizim ülkemizden daha eski olan ülkelerde akarsu kıyılarının bir yeşil sistemin omurgası olarak görüldüğü örneklerin sayısı daha fazladır. Bu anlamda en güzel örneklerden biri, Boston kentinde 'Emerald Necklace' (Zümrüt Kolye) adı verilmiş olan, Muddy River kenarındaki yeşil sistemdir. Bu yeşil sistem, kent içinden geçen Muddy River'ın kenarında, irili ufaklı parklar, gezinti yolları ve yeşil bantlarla süren 445 hektarlık bir alanı kaplamakta (Emerald Necklace Map, 2020) ve yaklaşık 12 kilometrelik bir güzergâh üzerinde bulunmaktadır (Boston, 2020). Emerald Necklace, yeşil alanların birbirleriyle olan bağlantılarını akarsu izi takip edilerek gözeten kent ölçeğinde bütüncül bir kurguya sahiptir. Akarsu kıyılarını referans alan bir yeşil sistem kurgusu, içinden akarsu geçen tüm kentlerde su ile kurulan bağlantının güçlendirilmesi bağlamında dikkate değerdir.

Analiz için ayrıştırılan bölgeler değerlendirildiğinde, pek çoğunda yapılaşma, Porsuk'a oldukça yakın noktalardan başlamakta ve genel itibariyle yoğun ve çok katlı bulunmaktadır. Özellikle bu konumlarda, çayın kullanıcı ile etkileşimi, büyük ölçüde kısıtlı kalmaktadır. Porsuk'un kullanıcı ile kurduğu iletişimin sürekliliğini, yapıların manzarası olmasından öte, kenarındaki kullanım çeşitliliği üzerinden sağlamak, kentlinin suyla kurduğu bağlantıyı güçlü kılmak adına gerekli görülmektedir. Doğa ile uzlaşısı daha yüksek ve doğal alanlara daha fazla yer açan bir anlayışla geliştirilecek plan ve projelerin, bu bağlantının güçlendirilmesi anlamında önemi büyüktür. Yaya yolları ve bisiklet yollarının sürekliliğinin sağlanması da etkileşim amaçlı geliştirilebilecek bir başka planlama ve tasarım alternatifidir. Kanlıkavak Parkı'nı içine alan 1. Bölgede olduğu gibi, kentteki alan kullanımının el verdiği parklar, mesire alanları gibi uygun kısımlarda; bu bölgenin karşı kıyısına denk gelen 2. Bölge başta olmak üzere Şeker Fabrikası ve Kentpark bölgelerinde de bisiklet yollarına yer verilebilir. 
Bu çalışma kapsamında gerçekleştirilen mekânsal analiz; belirlenen bölgelerde, kullanıcının Porsuk Çayı ile bağlantı kurma yerlerine, araçlarına ve araçlardaki çeşitlenmeye göre düzeylerine ilişkin bilgi vermektedir. Yürütülen analizin, özellikle yeni büyümekte olan, içinden akarsu geçen kentlerde akarsu kıyısında gerçekleştirilmesi düşünülen plan ve projeler için mekân bağlamında bir çerçeve sunabileceği düşünülmektedir. Porsuk'u da içine alan gelecekteki plan ve projeler özelinde de suyun diğer doğal bileşenlerle ve kentli ile etkileşimine daha çok yer veren çözümlere odaklanılması, kentin Porsuk ile birlikte anılan kimliğinin sürdürülebilmesine katkı sağlayacaktır. Araştırma alanı, akarsu kıyısı yerine akarsu koridoru kapsamında daha geniş alanı içerecek biçimde genişletilerek kentin daha büyük parçalarına ilişkin değerlendirmeler de yapılabilir. Bununla birlikte bölgelerin büyütülmesi, her bir bölgenin ayrı çalışmalar ile tek tek ele alınmasını gerektirebilecektir. Bu çalışma, Porsuk'un Eskişehir kenti içinde kalan hemen tüm kısmındaki kıyısına dair genel bir değerlendirmeye ulaşmayı amaçladığından, çalışma alanı olarak 7 km'ye varan uzun bir güzergâha yayılmıştır. Çalışma alanının büyüklüğü nedeniyle, analizlerde alanın izin verdiği ölçüde bir derinleşmeye gidilmiştir. Bu nedenle çalışmanın; su ve kullanıcı etkileşimine dair mekânsal bağlamda yürütülecek bir araştırma için ağırlıklı olarak yöntemsel bir katkı sunacağı düşünülmektedir. Ortaya konulan yöntem çerçevesinden faydalanılarak; SGA ve kullanım araçlarına dair analiz ya da benzeri analizler, alt bölgelerde ve daha detaylı olarak yürütülebilir. Buna ek olarak, deneyim aracı düzeylerine dair hesaplama, araştırmaya kullanıcı tutum ve tercihleri dahil edilerek göstergelere belli ağırlıklar verilmesi yoluyla geliştirilebilir. Kullanım araçları, ilerideki çalışmaların kapsamına göre, konumsal kategoriler yerine aktif ve pasif kullanılma durumlarının, çeşitlerinin ve kullanım amaçlarının dikkate alındığı kategoriler kapsamında da incelenebilir. Bunların yanı sıra kullanım araçlarının sayıları, sıklıkları ve/veya kullanım yoğunluklarının da çıktıları zenginleştirmek anlamında değerlendirmeye alınabileceği düşünülmektedir. 


\section{Etik Standart ile Uyumluluk}

Çıkar Çatışması: Yazarlar, bu makale için herhangi bir çıkar çatışmasının olmadığını beyan ederler.

Etik Kurul İzni: Bu çalışma için etik kurul iznine gerek yoktur.

\section{KAYNAKÇA:}

Abshirini, E., \& Koch, D. (2016). Rivers as integration devices in cities. City, Territory And Architecture , 3/1, 1-21.

Adler, R. W. (2007). Restoring the environment and restoring democracy: Lessons from the Colorado River. Virginia Environmental Law Journal , 25/1, 55-104.

Boston, 42 ${ }^{\circ} 18^{\prime} 52.25^{\prime \prime}$ N 7105'10.95" W. Google Earth. Erişim Tarihi: 18 Eylül, 2020, https://www.earth.google.com

Cullen, G. (1961). Townscape. London: Architectural Press.

Çalışkan, O. (2017). Kentsel tasarım. S. S. Özdemir, Ö. B. Özdemir Sarı, \& N. Uzun İçinde, Kent Planlama, Ankara: İmge Kitabevi, 387-425.

Emerald Necklace Map. (2020). Emerald Necklace Conservancy. Erişim Tarihi: 18 Eylül, 2020, https://www.emeraldnecklace.org/park-overview/emerald-necklace-map/

Esbot Seferleri. (2015). Eskişehir Büyükşehir Belediyesi. Erişim Tarihi: 15 Ağustos, 2019, http://www.eskisehir.bel.tr/sayfalar.php?sayfalar_id=11

Eskişehir Merkez Taşınmaz Kültür Varlıkları. (2016). Kültür ve Turizm Bakanlığı. Erişim Tarihi: 15 Ağustos, https://korumakurullari.ktb.gov.tr/TR-133414/merkez.html

Eskişehirliler Kanlıkavak’ta Nefes Alıyor (2018). Odunpazarı Belediyesi. Erişim Tarihi: 15 Ağustos 2019, http://www.odunpazari.bel.tr/haber-1365-eskisehirliler_kanlikavakta_nefes_aliyor

Gençlik Kupası Kano Yarışları. (2018). Eskişehir Büyükşehir Belediyesi. Erişim Tarihi: 15 Ağustos, 2019, http://www.eskisehir.bel.tr/icerik_dvm.php?icerik id=3882\&cat_icerik=1\&menu id=24

Havadan Eskişehir. (2016). Esvizyon. Erişim Tarihi: 29 Temmuz 2019, http://esvizyon.com/tr-TR/fotogaleri/198/havadan\%20eskisehir/1? =1532822400033 
Horsman, T. (2013). Developing sign design guidelines for sense of place: A practical application for interpreting Bidwell Park. Unpublished Master Thesis. Cincinnati.

Özeren, M., Hepcan, Ş. (2013). Kent içi akarsu koridorlarının canlandırılması: İzmir kent merkezi örneği, TMMOB 2. İzmir Kent Sempozyumu Bildiri Kitabı, İzmir, 837- 847.

Özkut, D. (2017). Eskişehir'de modern hafizanın yerel izleri. TÜBA-KET, 16/2017, 35-66.

Silva, J. B., Saraiva, M., Ramos, I. L., \& Bernardo, F. (2012). Improving visual attractiveness to enhance city-river integration - A methodological approach for ongoing evaluation. Planning Practice \& Research, 28/2, 163-185.

Şimşek, G. (2011). Kentsel akarsuların mekânsal entegrasyon açısından yeniden ele alınması . A. V. Eraydın İçinde, 2. Kentsel ve Bölgesel Araştırmalar Sempozyumu Bildiri Kitabl, Ankara, 549-559.

Şimşek, G. (2014). River rehabilitation with cities in mind: The Eskişehir case. METU Journal of Faculty of Architecture, 31/1, 21-37.

Fukushima, Y., Uchida, T. (2016). Questionnaire survey of riverfront residents after nature-oriented water amenity development project of a minor river in a built-up area, Yoshinori Kanjo, Souichi Saeki, Masafumi Muraji, Eiji Shikoh, Noritsugu Kometani, Tetsu Tokuono (Eds.) in Memoirs of the Faculty of Engineering Osaka City University. V.57, 11-26. 